\title{
The Conquering influence of the Nano extracts of pomegranate peels and pistachio leaves in
} amelioration of acute liver failure

\author{
Sohair Aly Hassan ${ }^{1}$, Olfat Hammam², SaharAwdallahHussein ${ }^{3}$ and Wessam Magdi Aziz ${ }^{1}$ \\ ${ }^{1}$ Therapeutic Chemistry Department, National Research Centre, Dokki, Cairo, Egypt. \\ ${ }^{2}$ Histopathology Departments, TheodorBilharz Research Institute. \\ ${ }^{3}$ Phytochemistry and plant systematics Dept, National Research Centre, Dokki, Egypt.
}

\section{Abstract:}

Objective: Acute liver failure (ALF) is a clinical condition with an unclear history of pathophysiology, making it a challenging task for scientists to reverse the disease in its initial phase and to help the liver re-function as usual: this study was proposed to estimate the hepatoprotective effects of Punicagranatum peel andPistaciaatlanticaleaves as a multi-rich antioxidants ingredients either in their normal and/or in their nano forms against thioacetamide induced acute liver failure in a rodent model. Method:Sixty male Wistar rats were divided into six equal groups, the first group employed as a control; the second group was given a dose of thioacetamide (TAA)-350 mg/bwip., from the third to the sixth group received TAA $\square 2 \mathrm{ml}$ of $100 \mathrm{gm}$ of aqueous extracts of PunicagranatumL and Pistaciaatlanticaeither in their normal and/or Nano forms consecutively along 2 weeks. Results: recorded significant elevation in liver enzymes, lipid profiles, LPO and NO with marked significant decrease in GSH and SOD accompanied by elevation in inflammatory cytokine ( IL6,TNF- $\alpha$ and AFP) in addition to a noticeable increase in $\mathrm{HSP}_{70}$ level \& degradation in DNA respectively in TAA challenged group. However significant and subsequent amelioration of most of the impaired markers has been observed with ipnano treatment of both extracts.Conclusion: The current results highlighted the high performance of both plant nano extracts and their hepatoprotective impact and their possible therapeutic role in the amelioration of TAA induced acute liver failure in experimental animals.

Keyword: Acute liver failure, thioacetamide, HPLC, nano extracts, TNF- $\alpha$, IL6.

*Corresponding author: Sohair Aly Hassan : e-mail: sohaireslamaya @ hotmail.com Therapeutic Chemistry Department. National Research Center. Cairo/Egypt.

33 El-Buhouth Street, Dokki, Cairo. Post Code. 12622. Tel: +2-01013131024 


\section{Introduction}

Acute failure of the liver/ALF is a disease characterized by a rapid and significant impairment of hepatocyte function in patients with normal liver function [1]. Hepatic encephalopathy and death levels of up to $80 \%$ are caused by ALF, even if intensive care is given $[2,3,4,5,6]$. Liver transplantation has been shown to be the most effective therapy for ALF, but this therapeutic choice constrained by the lak of donor organ. The use of bio artificial livers is one of the other approaches to treatment, to overcome the time gap for transplantation or regeneration of the liver [7,4,8,9]. The effectiveness of new ALF treatment methods has not yet been fully explored [5, 9] and even the knowledge of the ALF pathophysiology is still inadequate [2,6]. So there is a necessitates to search for the discovery and implementation of efficacious safe nutraceuticals rather than chemically synthesized as well as an Optimum experimental ALF models with features similar to human disorder.

Thioacetamide (TAA) is a class of chemicals that most recommended to generate the disease model in the very shortest duration ${ }^{[10,11]}$. TAA has long been known as a hepatocyte toxic agent; The TAA biotransformation cycle into thioacetamide sulfoxide (TAAS) mainly takes place through P450 (CYP) cytochrome pathway, (CYP2E enzyme is mainly involved here) ${ }^{[12]}$. The binding of these metabolites to liver macromolecules dramatically inspire a moiety of reactive oxygen species in turn induces acute centrilobular necrosis of the liver ${ }^{[13]}$. These results of the liver diseases such as cirrhosis and primary cancer of the liver ${ }^{[14]}$ TAA will overpower the body's antioxidant defense mechanisms and spread rapidly to neighboring tissues to destroy cell vital ingredients that ultimately enter DNA. ${ }^{[15] .}$ There is currently a widespread interest in the use of natural products specially the dietary polyphenols, which are considered safe and less side-effect compared to the synthesis of chemical drugs and the best hepatoprotective agents due to their synergistic action ${ }^{[16,17]}$. Dietary polyphenols, especially those in vegetables, fruits and legumes, have been reported to be capable of achieving a balance between natural antioxidants and free radicals by enhancing the role of natural antioxidant enzymes such as glutathione reductase (GR superoxide dismutase (SOD), glutathione peroxidase (GPx), and glutathione S transferase (GST) by specifically capturing free radicals ${ }^{[18]}$. 
Sweet fruit belongs to Punicaceae family is known worldwide as pomegranate / Punicagranatum $\boldsymbol{L}$ because of its health value from all its components ${ }^{[19,20,23]}$. Although anti-inflammatory properties and resistance to exponential increases in glucose levels in diabetic rat models have been reported for pomegranate flowers and juices ${ }^{[21,22]}$ More and more attention has been paid recently to the pomegranate husk / peel as it has been confirmed to be of great benefit to a broad

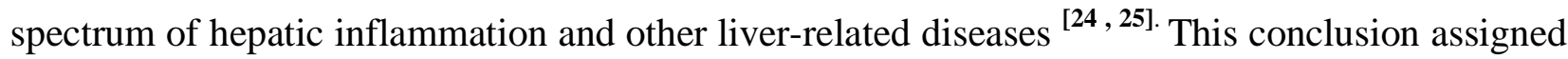
according to earlier studies has shown that pomegranate peels have a higher content of phenolic compounds than fruit pulp including a group of flavonoids (catechins, anthocyanins and other complex flavonoids) and hydrolyzing tannins (punicalin, pedunculagin, punicalagin, gallic and ellagic acid) ${ }^{[21,26]}$.Pomegranate has shown evidence concerning preventive cancer-chemo property ${ }^{[27]}$ Reducing the oxidative stress mediators that extensively contribute to its phenolic compounds and serve as a powerful tool for free radical scavenging properties makes it unique [28]. Pistachio is a type of nut produced by approximately 20 species of shrub such as Pistaciaterebinthusn, Pistaciavera, Pistaciakhinjuk ,Pistacialentiscus, and Pistaciaatlantica belonging to the Cashew family (Anacardiaceae) ${ }^{[29]}$.This Genus Pistacia is characterized by the presence of a wide range of diverse compounds such as flavonoids, triterpenes, sterols and phenolic compounds. The phenolic compounds are abundant in different parts of this genus ${ }^{[30,31]}$. Pistaciaatlantica has been shown to have antibacterial properties and is used in eczema, throat infections, kidney stones, asthma and stomach aches as an astringent, antipyretic, antiinflammatory, antiviral, and stimulating agent ${ }^{[32]}$. Previous studies of Photochemistry and chromatographic fingerprints of this plant indicated that it contain phenolic compounds (such as gallic acid, quinic acid, tetragalloylquinic acid,) and triterpenoids, pinene, terpinolene ${ }^{[33]}$.Although the pistachio is common, it was not sufficiently investigated as a safe eaten nut ${ }^{[34]}$. The use of nanoparticles science is completely exhibit an improved novel properties compared with larger particles of the bulk materials due to the variations in the particles size, morphology and distribution. Nowadays, noble metals like silver, gold and platinum are commonly used in green chemistry without using toxic chemicals via a method involve use of environmentally friendly processes as a simple and viable alternative to synthetic chemicals and physical processes ${ }^{[35]}$. Several researchers reported the biosynthesis and possible applications of metal nanoparticles by plant leaf extracts ${ }^{[36]}$. 
This work is the first to clarify the potential role of pomegranate peel and pistachio leaves extracts in their natural and nano forms to alleviate TAA-induced hepatic failure in rat model. This research further explores a potential mechanism of action for both forms that could have therapeutic effects.

\section{Materials and method}

\subsection{Chemicals}

All Chemicals, Silver nitrate and thioacetamide were procured from Sigma-Aldrich (USA). The different solvents and chemicals used in the present study were of high analytical grade and purchased from a local vendor.

\subsection{Authentication \& preparation of the plant extracts}

The pomegranate fruits were purchased from local market at Cairo city, Egypt, 2018 and Pistaciaatlantica leaves were collected from Beniwalid, Libya 2017.The plants material were identified and authenticated by a plant taxonomist at the National Research Center Herbarium (Cairo, Egypt) according to ${ }^{[37]}$. Where a voucher specimen has been deposited for future reference. The pomegranates was washed, cut into small pieces and left to dry in air and the complete dryness occurred in an oven at $50^{\circ} \mathrm{C}$. The dried peels were grounded to fine powder. The pomegranate peel (PO) extract was obtained by addition 100 gm of pomegranate peel powder with $1000 \mathrm{ml}$ boiled distilled water [Erlenmeyer flask] and boiled for 10 minutes with the help of whatman filter paper(NO.3), the boiled materials were filtered toget aqueous fruit peel extract, which was used as such for metal nanoparticles synthesis. Finally stored at $-4{ }^{\circ} \mathrm{C}$ for further experiments .About $100 \mathrm{~g}$ of dried powder of Pistaciaatlantica leaves (PS) transferred into a $1000-\mathrm{mL}$ Erlenmeyer flask with $500 \mathrm{~mL}$ of distilled water along with boiling for $30 \mathrm{~min}$. The aqueous extract was filtered and stored at $4{ }^{\circ} \mathrm{C}^{[33] \text {. }}$ 


\section{High performance liquid Chromatography [HPLC]:}

HPLC analysis was carried out using an Agilent 1260 series. The separation was carried out using Kromasil C18 column (4.6 mm x $250 \mathrm{~mm}$ i.d., $5 \mu \mathrm{m})$.The mobile phase consisted of water (A) and $0.05 \%$ trifluoroacetic acid in acetonitrile (B) at a flow rate $1 \mathrm{ml} / \mathrm{min}$. The mobile phase was programmed consecutively in a linear gradient as follows: 0 min (82\% A); 0-5 min (80\% A); $5-8 \min (60 \% \mathrm{~A}) ; 8-12 \min (60 \% \mathrm{~A}) ; 12-15 \min (85 \% \mathrm{~A})$ and $15-16 \min (82 \% \mathrm{~A})$. The multi-wavelength detector was monitored at $280 \mathrm{~nm}$. The injection volume was $10 \mu \mathrm{l}$ for each of the sample solutions. The column temperature was maintained at $35^{\circ} \mathrm{C}$. [Chart 1a,b], while Pistaciaatlantica was evaluated according to the methods described for the identification of major phytochemical components in the extract $\left.{ }^{[38}\right]$.

\subsection{Synthesis of nanoparticles}

To synthesis silver nanoparticle (1MLAgNPs), silver nitrate $(0.017 \mathrm{~g})$ was added in $100 \mathrm{ml}$ of double distilled water to prepare $1 \mathrm{mM}$ silver nitrate solution. Then, $1 \mathrm{ml}$ of aqueous extract of both extracts was added to $50 \mathrm{ml}$ of silver nitrate $(1 \mathrm{mM})$ solution to obtain silver nanoparticles, as shown in Fig1a, b.

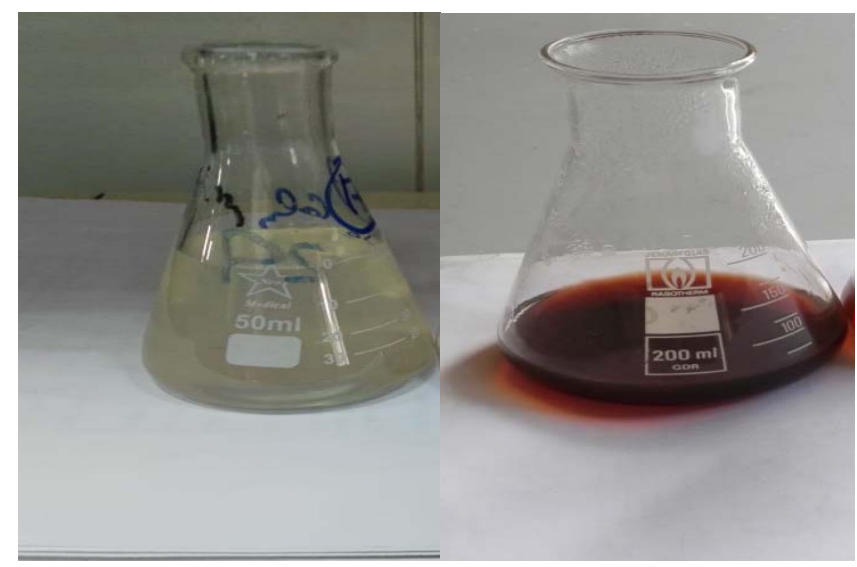
a] Nano- Pistachio
b] Nano- pomegranate

Fig .1: The visual observation of color changes of nano extracts.

This setup was incubated in a dark chamber to minimize photo-activation of silver nitrate at room temperature under static conditions for nucleation of the silver nanoparticles. Reduction of 


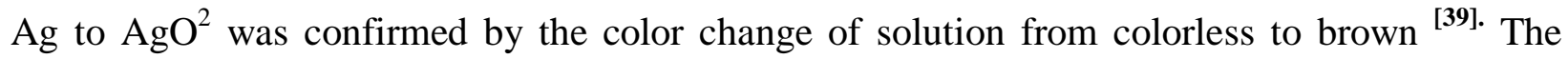
suspensions were subjected to centrifugation for the pellets to settle, which were then dried using a vacuum drier18 2.5 Characterization of the silver nanoparticles to measure the maximum production and activity of AgNPs, UV-visible spectra were taken using a Shimadzu UV-visible spectrophotometer.

\subsection{Characterization of synthesized silver nanoparticles}

2.4.1. UV-Vis spectral analysiswas done by using Shimadzu Visible spectrophotometer (UV-1800, Japan). The periodic scans of the optical absorbance between 300 and $700 \mathrm{~nm}$ with a doublebeam UV-Visible spectrophotometer (Carry 100 with tungsten halogen light sources) were performed to investigate the reduction of silver ions by leaf extract. The presented results were obtained at room temperature.

2.4.2. Field emission scanning electron microscopy (FESEM): The morphology, particle dispersion, and chemical composition of the prepared Nano-structures were investigated by (FESEM) (Quanta 450) equipped with EDS at accelerating voltage $30 \mathrm{kV}$. Cross cut samples were prepared by fracturing the membranes in liquid nitrogen. A thin layer of gold was coated on all the samples before microscopic analysis

2.4.3. The potential of the biosynthesized AgNPs was performed on Malvern Zeta size Nano series compact scattering spectrometer (Malvern Instruments Ltd.; Malvern, UK).

\subsubsection{Transmission electron microscopy (TEM)}

The particle size and surface morphology were analyzed usinga JEOL JEM 1230 transmission electron microscope (JEOL Ltd., USA). The samples for TEM analysis were cut into slices of a nominal thickness of $100 \mathrm{~nm}$ using an ultra-microtome with a diamond knife at an ambient temperature. The cut samples were supported on a copper mesh for this analysis. 


\subsection{Animals}

A total of 60 Wistar ratsaged 2 months weighing 180-200 g, were taken from the breeding laboratory of National research center and kept in animal care facility. Rats were kept in polypropylene cages at room temperature with a $12 \mathrm{~h}$ light-dark cycle and relative humidity of $60 \% \pm 1 \%$. Animals were provided purified water ad libitum with standard laboratory rat chow. The study was approved by the animal ethics committee of Institutional Review Board of National Research Center, and the ethical guidelines for use and care of laboratory animals in experiments were strictly followed.The experimental animal protocol was designed to minimize pain or discomfort to the animals. TAA (Sigma, Aldrich Chemical Co., USA)) was dissolved in physiological saline and the appropriate selected dose was injected $350 \mathrm{mg} / \mathrm{BW}$ i.p. in $1-\mathrm{ml}$ volume $^{[40]}$.

\subsubsection{Experimental protocol}

The rats were divided into 6 groups consisting of 10 rats each. Rats injected intraperitoneal (IP) with freshly prepared TAA $350 \mathrm{gm} / \mathrm{BW}$ a single injection ${ }^{[40] .} 5 \%$ glucose solution was added to the drinking water to prevent dehydration $24 \mathrm{hrs}$ post injection, daily IP dose of $2 \mathrm{mls}$ of normal \& Nano pomegranate extracts, were given to the third and fourth group respectively. The fifth $\&$ sixth groups were given the normal and nano forms of pistachio extracts in a dose of $2 \mathrm{mls}$ along two weeks. While the first group and second groups were kept as negative and positive control groups. The survival rate \& BW was monitored along the experiment period. $24 \mathrm{hr}$ after the last dose of respective assigned treatments, the whole animals were sacrificed by cervical decapitation. Blood samples were immediately collected into sterilized tubes and let stand for 10 minutes to clot. The serum was separated by centrifugation at $3000 \mathrm{rpm}$ for $10 \mathrm{~min}$ and stored at$80^{\circ} \mathrm{C}$ for assessment of liver functions and another biochemical analysis. Liver tissues were dissected and divided into two parts, the first part was fixed in $10 \%$ formaldehyde solution for histopathological and immunohistochemical examinations and the second part (1 $\mathrm{g})$ was homogenized (1:5 w/v) in ice cold $0.1 \mathrm{M}$ potassium phosphate buffer $(\mathrm{pH} 7.4)$. The homogenate

was centrifuged at 4,000 rpm for 15 minutes and the supernatant collected and liquated in eppendorf tubes and stored a $-20{ }^{\circ} \mathrm{C}$ for different biochemical determinations. 


\subsection{Biochemical analysis}

The liver function indices, Serum alanine aminotransferase (ALT), aspartate aminotransferase (AST) and alkaline phosphatase (ALP),total lipid profile (TP), total cholesterol (TC), triglyceride (TG )and total bilirubin were estimatedusing biodiagnostic kits (Biogamma, Stanbio, WestGermany). The oxidative stress markers, lipid peroxidation (LPO), glutathione (GSH), superoxide dismutase (SOD) and nitric oxide (NO), were evaluated using the methods of $\left[\mathbf{4 0 , 4 1 , 4 2 , 4 3 , 4 4 ]}\right.$ respectively. Liver total protein contents were estimated by the method of ${ }^{[45]}$. The DNA fragmentation index was evaluated using the comet assay technique as described by [46]. The proinflammatory cytokines TNF- $\alpha$, IL-6, Alpha fetoprotein (AFP) and HSP 70 were assayed using commercially available ELISA kits (R\&D, Minneapolis, MN).

\subsection{Histopathological studies}

A portion of the liver was preserved in $10 \%$ buffer formalin for at least $24 \mathrm{hr}$. and then processed and embedded in paraffin according to the standard protocol. Sections were cut into $5 \mu \mathrm{m}$ thick portions, transferred on to glass slides, and stained with haematoxylin and eosin (HE), observed microscopically for any histopathological and immunohistochemical changes as well ${ }^{[47]}$.

\subsubsection{Histopathological and immunohistochemical examinations}

Five $\mu \mathrm{m}$ thick sections of paraffinized liver stained with hematoxylin and eosin were examined histopathologically under Zeiss microscope (Carl Zeiss Microscopy GmbH 07745 Jena, Germany) with $\times 200$ magnification powers. For immunohistochemical examinations of IL6, TNF $\alpha$ were performed on liver sections cuts from the paraffin blocks with a commercially available Anti-mouse IL6, TNF $\alpha$ antibodies (Santa Cruz Biotechnology, CA, USA) at the optimal working dilution of 1:100. Briefly, slides were sectioned at $4 \mu \mathrm{m}$ on to positively charged slides (Superfrost plus, Menzel-Glaser, Germany) and the slides were stained on an automated platform (DakoAutostainer Link 48). Heat induced antigen retrieval was used for 30 min at $97^{\circ} \mathrm{C}$ in the high-PH EnVision ${ }^{\mathrm{TM}}$ FLEX Target Retrieval Solution and the primary antibody was used at a dilution of 1 in 100.The percent of positively stained brown cytoplasm (IL6, TNF $\alpha$ ) were examined in 10 microscopic fields (under Zeiss light microscopy at x400). 


\subsection{Statistical analysis}

All data were expressed as mean \pm SD of ten rats in each group using the Co-stat computer program where an unshared letter is significant at $p \square<\square 0.05$. The correlations between all markers and inflammatory cytokines were analyzed using Pearson's correlation analysis test. The ROC-Curve method was done by SPSS version 16 and used to generate the Cut-off value. area under the curve, Sensitivity, Specificity. $\mathrm{P}<0.05$ was set to be level of significance ${ }^{[48] \text {. }}$ 


\section{Results:}

The current results revealed that the incubation of $50 \mathrm{ml}$ of $1 \mathrm{mM} \mathrm{AgNO} 3$ with $1 \mathrm{ml}$ of pomegranate extract for $24 \mathrm{~h}$ at the room temperature led to the synthesis of AgNPs as indicated by the development of the brown color (Fig.1).

Results of HPLC for pomegranate showed Gallic acid, chlorogenic acid and ellagic acid at concentrations of $2160.89,763.22$ and 97.60 were the major components of the extract (Table 1, chart 1a,b) while twenty-seven polyphenol compounds were detected in pistachio ${ }^{[38]}$, consisting of three major polyphenol groups, namely gallate, flavonoid and ellagic acid derivatives.
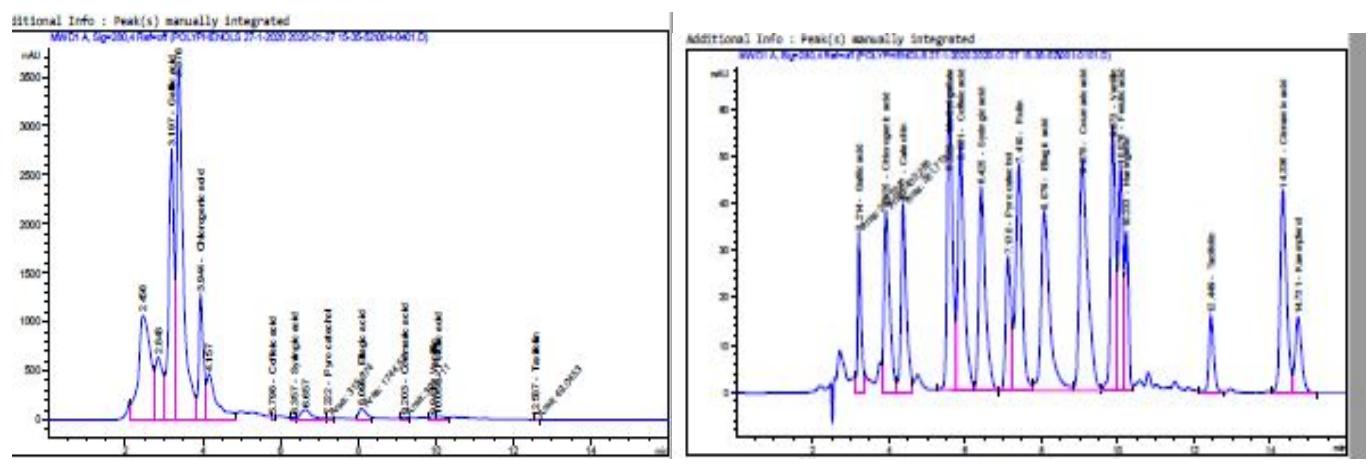

Chart [1a]:.High-performance liquid chromatography (HPLC) of polyphenolic compounds detected in water extracts of pomegranate peel water extract Chart [1b]: High-performance liquid chromatography (HPLC) of Standared polyphenolic compounds. 
Table 1: High-performance liquid chromatography of polyphenolic compounds detected in aqueous extracts of Punica granatum L

\begin{tabular}{|c|c|c|}
\hline CONTENTS & $\begin{array}{c}\text { RTIME } \\
\text { [MIN] }\end{array}$ & CONC. $(\mu \mathrm{G} / \mathrm{ML}=\mu \mathrm{G} / 0.1 \mathrm{G})$ \\
\hline Gallic acid & 3.214 & 2160.89 \\
\hline Chlorogenic acid & 3.925 & 763.22 \\
\hline Catechin & 4.377 & 0.00 \\
\hline Methyl gallate & 5.589 & 0.00 \\
\hline Coffeic acid & 5.881 & 8.05 \\
\hline Syringic acid & 6.425 & 8.22 \\
\hline Pyro catechol & 7.130 & 32.00 \\
\hline Rutin & 7.410 & 0.00 \\
\hline Ellagic acid & 8.079 & 97.60 \\
\hline Coumaric acid & 9.075 & 6.98 \\
\hline Vanillin & 9.873 & 9.55 \\
\hline Ferulic acid & 10.076 & 18.78 \\
\hline Naringenin & 10.233 & 0.00 \\
\hline Taxifolin & 12.449 & 4.67 \\
\hline Cinnamic acid & 14.336 & 0.00 \\
\hline Kaempferol & 14.731 & 0.00 \\
\hline
\end{tabular}

\subsection{Characterization of silver nanoparticles by UV-VIS absorption spectroscopy:}

The absorption spectra of aqueous peel extracts obtained from Pomegranate plants, aqueous leaves extracts obtained from Pistachio were compared with the absorption spectra of silver nanoparticles prepared using these extracts in order to reveal the formation of silver phytonanoparticles. Further, UV-visible spectrophotometric analysis of nanoparticles showed the maximum absorption of nanoparticles of both PO and PS at a wavelength of $425 \mathrm{~nm}$. 
3.2. Electron Microscope scanning: Scanning electron microscope analysis showed that the synthesized AgNPs are polydispersed with particle size range from 19-65 nm for Pistachio leaves Fig. 2.and 12-18 nm for Pomegranate peel Fig. 3.

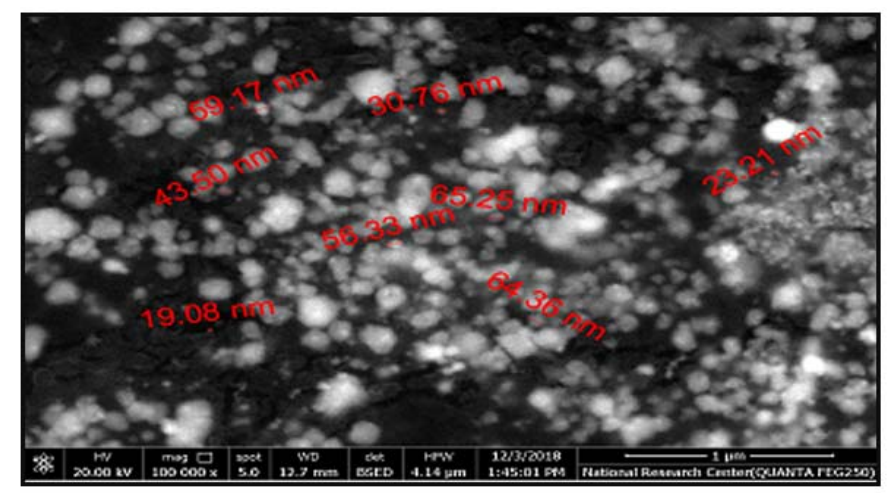

Fig. 2.SEM Pistachio nanoparticle micrograph with a size range from 19-65 $\mathrm{nm}$.

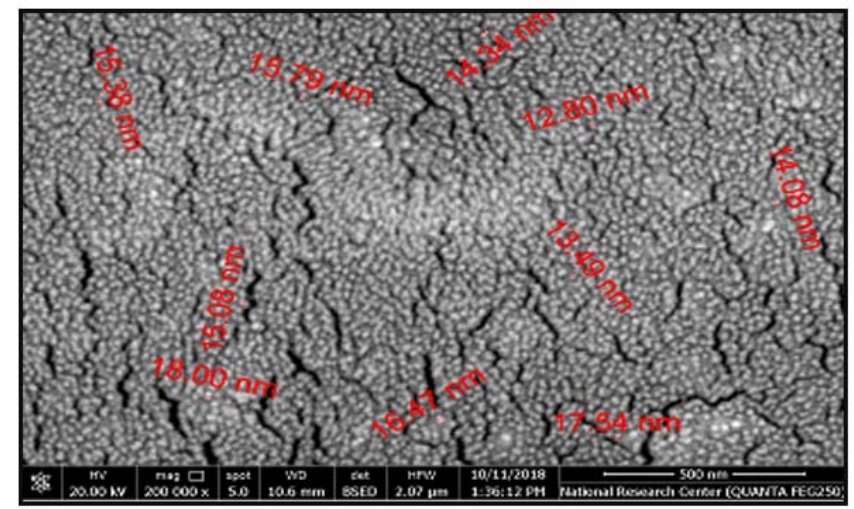

Fig. 3. SEM Pomegranate nanoparticle micrograph with a size range from $12-18 \mathrm{~nm}$.

\subsection{Evaluation of physical stability of silver phytonanoparticles:}

The physical stability of the silver nanostructures was evaluated in terms of $\xi$-potential. The surface charge of all the silver nanostructures of Pomegranate peel and Pistachio leaves were ranging from -10.6 to $-13.3 \mathrm{mV},-17.6-23.6 \mathrm{mV}$ respectively. 


\subsection{Transmission electron microscopy (TEM)}

TEM findings confirmed the spherical shape of the synthesized AgNPs with an average range of 4 to $42 \mathrm{~nm}$, showing that the AgNPs pomegranate size is $17 \mathrm{~nm}$ Fig.4, whereas the AgNPs pistachio average size was $15 \mathrm{~nm}$ Fig5.

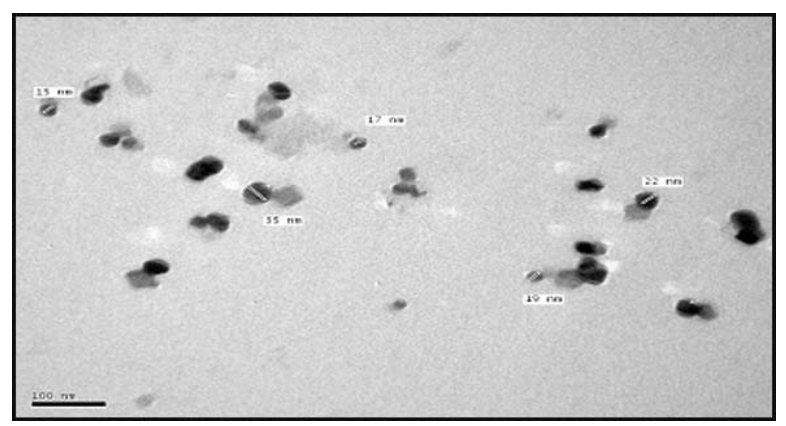

Fig. 4. Pomegranate silver nanoparticles TEM micrograph, appear in spherical shape with mean size of $17 \mathrm{~nm}$

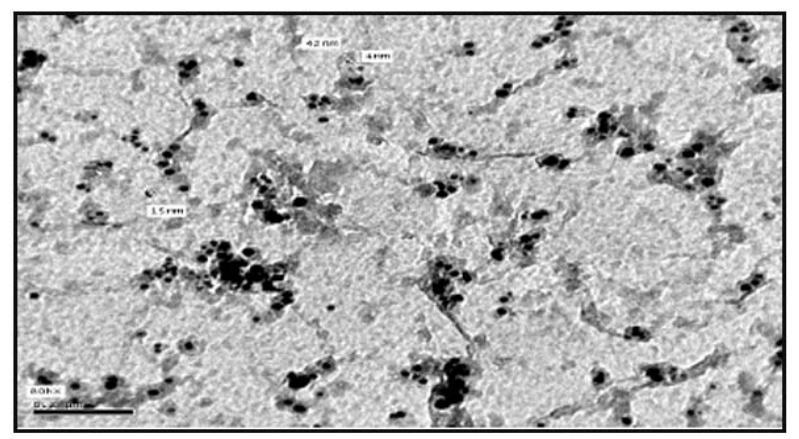

Fig. 5. TEM micrograph of Pistachio silver nanoparticles, appear in a- spherical shapewith average mean size of $15 \mathrm{~nm}$ 


\subsection{Effect of pomegranate and pistachio in their normal and Nano forms on liver functions,}

\section{lipid profile parameter:}

Upon administration of TAA, there was a marked increase in serum activity, liver function represented by (ALT, AST and ALP) as well as bilirubin to approximately 2.5, 2.8, 2.15 and 1.93 fold, respectively, as well as a marked increase in the lipid profile represented by TP, TG, TC to approximately 2.6, 3.2.2 fold, respectively, compared to the normal control group at $\boldsymbol{p}<0.0001$ (Table 2). Treatment of animals with pomegranate peel (PO) and pistachio leaves (PS) extract either in their normal or in Nano forms $(100 \mathrm{mg} / \mathrm{kg})$ significantly decreased ALT, AST, ALP levels. A notable increase in the level of bilirubin in comparison with the challenged TAA group at $\boldsymbol{p}<0.0001$ (Table 2). Hence, treatment showed very satisfied improvement levels as shown in Fig. 6. Nano pistachio group showed the most highly improved \% in liver function tests. On the other hand lipid profiles upon treatment with PO and PS in normal and Nano form a prominent significant reduction in (TP, TC, and TG) were recorded compared with TAA group at $\boldsymbol{p}<0.0001$ (Table 2). Therefore, we observed amelioration levels in these parameters as represented in Fig. 7. Whereas in total lipids, Pomegranate extract obtained the most percent improvement other than the remaining treatment classes, while Pistachio leaves extract showed a high percentage improvement in TC and TG parameters. (Fig. 7). 
Table. (2): Therapeutic effects of both of pomegranate, pistachio and their nanoparticles on liver functions and lipid profile.

\begin{tabular}{|c|c|c|c|c|c|c|}
\hline Groups Parameters & $\begin{array}{c}\text { Control } \\
\text { (-ve) }\end{array}$ & $\begin{array}{r}\text { TAA } \\
(+\mathbf{v e})\end{array}$ & TAA $+\mathbf{P O}$ & TAA+NPO & TAA+PS & TAA+NPS \\
\hline $\begin{array}{c}\text { ALT } \\
(\mathbf{U} / \mathbf{m l})\end{array}$ & $\begin{array}{c}48.6^{c} \\
\pm \\
7.40\end{array}$ & $\begin{array}{c}121.4^{a} \\
\pm \\
9.04\end{array}$ & $\begin{array}{c}48^{c} \\
\pm \\
6.81\end{array}$ & $\begin{array}{l}55.8^{c} \\
\pm \\
6.72\end{array}$ & $\begin{array}{c}79.6^{\mathrm{b}} \\
\pm \\
12.70\end{array}$ & $\begin{array}{c}47^{\mathrm{c}} \\
\pm \\
\mathbf{5 . 4 1}\end{array}$ \\
\hline $\begin{array}{c}\text { AST } \\
(\mathbf{U} / \mathbf{m l})\end{array}$ & $\begin{array}{l}54.4^{\mathrm{d}} \\
\pm \\
6.58\end{array}$ & $\begin{array}{c}157.2^{\mathrm{a}} \\
\pm \\
10.70\end{array}$ & $\begin{array}{c}85.25^{\mathrm{c}} \\
\pm \\
7.95\end{array}$ & $\begin{array}{c}113.8^{b} \\
\pm \\
9.67\end{array}$ & $\begin{array}{c}89^{c} \\
\pm \\
4.94\end{array}$ & $\begin{array}{c}74^{\mathrm{c}} \\
\pm \\
17.70\end{array}$ \\
\hline $\begin{array}{l}\text { ALP } \\
\text { (U/I) }\end{array}$ & $\begin{array}{c}108.48^{\mathrm{cd}} \\
\pm \\
17.16\end{array}$ & $\begin{array}{c}233.90^{\mathrm{a}} \\
\pm \\
15.72\end{array}$ & $\begin{array}{c}124.42^{c} \\
\pm \\
14.90\end{array}$ & $\begin{array}{c}154.28^{b} \\
\pm \\
16.58\end{array}$ & $\begin{array}{c}164.48^{b} \\
\pm \\
24.27\end{array}$ & $\begin{array}{c}91.42^{\mathrm{d}} \\
\pm \\
5.60\end{array}$ \\
\hline $\begin{array}{c}\text { Total Lipid (TP) } \\
\text { (g/dl) }\end{array}$ & $\begin{array}{l}0.402^{\mathrm{c}} \\
\pm \\
\mathbf{0 . 0 3 2}\end{array}$ & $\begin{array}{c}0.909^{\mathrm{a}} \\
\pm \\
0.06\end{array}$ & $\begin{array}{l}0.439^{c} \\
\pm \\
0.035\end{array}$ & $\begin{array}{c}\mathbf{0 . 5 8}^{\mathrm{b}} \\
\pm \\
\pm \\
\mathbf{0 . 0 5 7}\end{array}$ & $\begin{array}{c}0.609^{b} \\
\pm \\
0.062\end{array}$ & $\begin{array}{l}0.610^{b} \\
\pm \\
\pm 0.066\end{array}$ \\
\hline $\begin{array}{c}\text { Total cholesterol } \\
\text { (TC) } \\
\text { (mg/dl) }\end{array}$ & $\begin{array}{c}40.20^{c} \\
\pm \\
1.92\end{array}$ & $\begin{array}{c}90.02^{\mathrm{a}} \\
\pm \\
2.12\end{array}$ & $\begin{array}{c}63.49^{b} \\
\pm \\
2.14\end{array}$ & $\begin{array}{c}36.22^{\mathrm{d}} \\
\pm \\
2.18\end{array}$ & $\begin{array}{c}34.52^{\mathrm{d}} \\
\pm \\
\mathbf{0 . 7 1}\end{array}$ & $\begin{array}{c}36.05^{d} \\
\pm \\
2.70\end{array}$ \\
\hline $\begin{array}{c}\text { Total glyceride } \\
\text { (TG) } \\
\text { (mg/dl) }\end{array}$ & $\begin{array}{c}96.32^{\mathrm{e}} \\
\pm \\
12.51\end{array}$ & $\begin{array}{l}297.1^{\mathrm{a}} \\
\pm \\
18.9\end{array}$ & $\begin{array}{c}146.08^{d} \\
\pm \\
15.12\end{array}$ & $\begin{array}{c}196.6^{c} \\
\pm \\
22.45\end{array}$ & $\begin{array}{c}278.2^{\mathrm{a}} \\
\pm \\
9.73\end{array}$ & $\begin{array}{c}250.8^{b} \\
\pm \\
8.75\end{array}$ \\
\hline $\begin{array}{c}\text { Total bilirubin } \\
\text { (TB) } \\
\text { (mg/dl) }\end{array}$ & $\begin{array}{l}1.172^{d} \\
\pm \\
0.115\end{array}$ & $\begin{array}{c}2.26^{b} \\
\pm \\
0.22\end{array}$ & $\begin{array}{c}1.83^{\mathrm{c}} \\
\pm \\
0.08\end{array}$ & $\begin{array}{c}2.57^{b} \\
\pm \\
0.22\end{array}$ & $\begin{array}{c}3.44^{\mathrm{a}} \\
\pm \\
0.095\end{array}$ & $\begin{array}{c}2.57^{\mathrm{b}} \\
\pm \\
0.33\end{array}$ \\
\hline
\end{tabular}

- Each group has a mean $\pm \mathrm{SD}$ of ten rats.

- Statistical analysis was conducted using a one-way variance analysis (ANOVA) using the Co-Stat computer program with the lowest level (LSD) between $\mathrm{p}<0.05$ classes.

- Groups with the same letters are not significantly different, whereas those with different letters vary considerably at $\mathrm{p}<0.05$. 


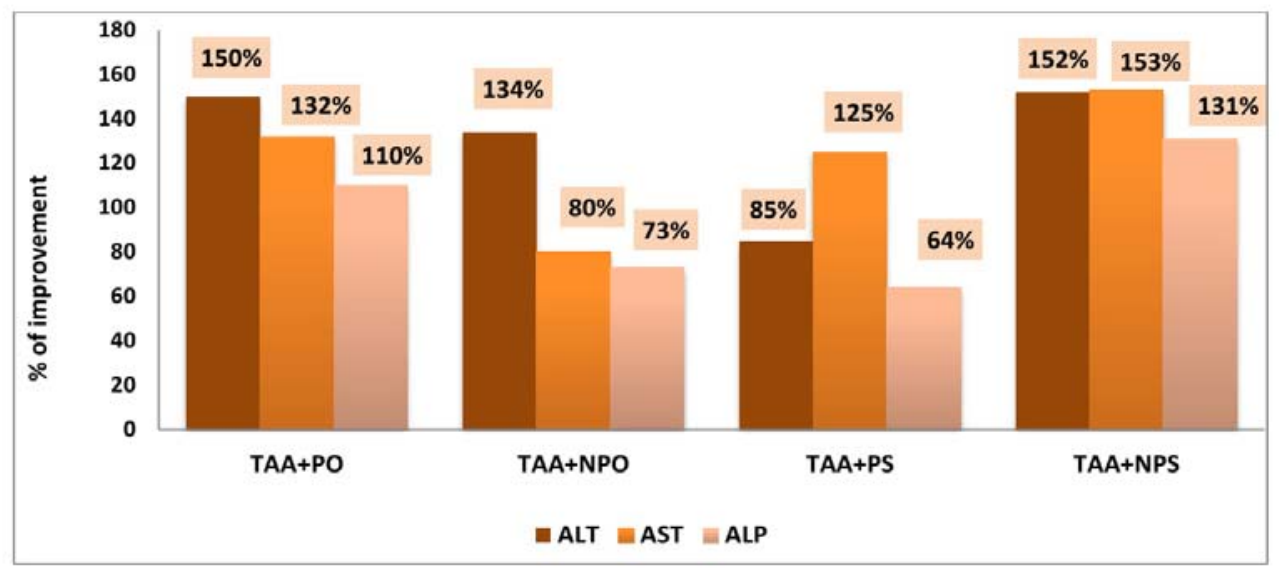

Fig. 6: Therapeutic effects of both of Pomegranate and Pistachio and their nanoparticle forms on serum ALT, AST and ALP. *Values are expressed as \% of improvement related to normal control and thioacetamide groups.

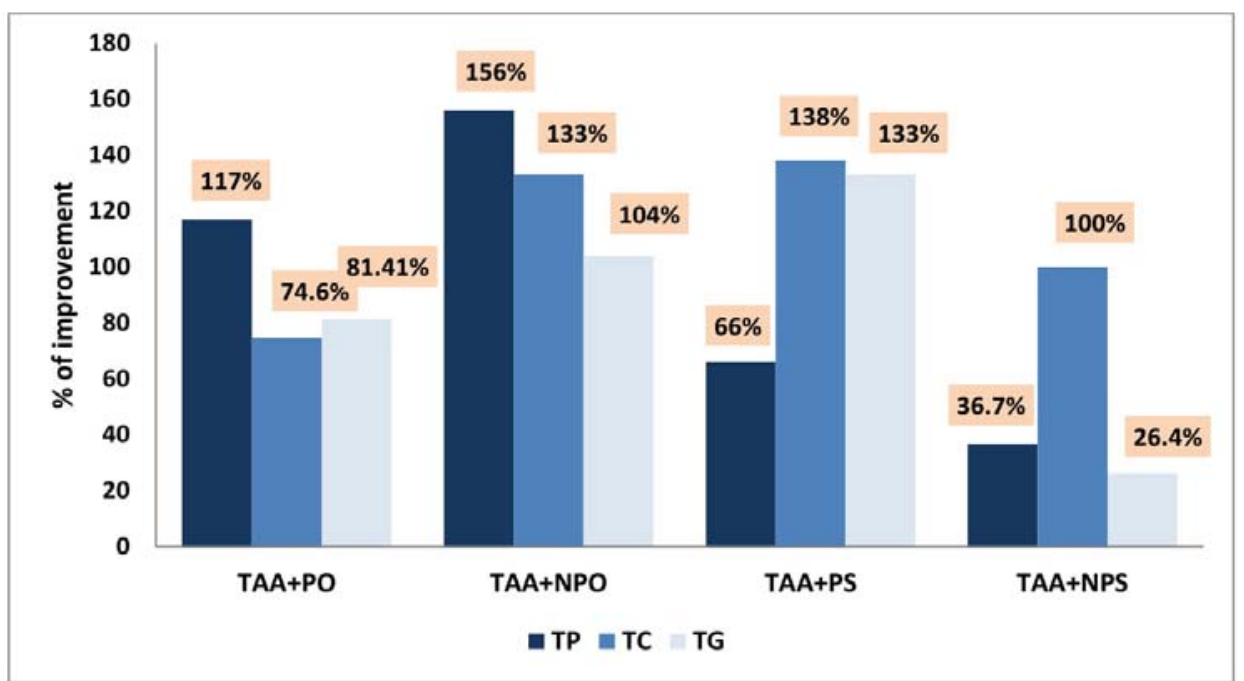

Fig.7. Therapeutic effects of both of Pomegranate and Pistachio and their nanoparticle forms on serum Total lipid, Total cholesterol and Total glyceride. ${ }^{*}$ Values are expressed as $\%$ of improvement related to normal control and thioacetamide groups. 


\subsection{Effect of pomegranate and pistachios in their normal and nanoforms on oxidative stress:}

GSH content, SOD activity, LPO and Nitric oxide (NO) levels were taken as markers of oxidative status. An obvious depletion was seen in the levels of GSH \& SOD with a prominent increase in each of LPO and NO levels in the challenged TAA intoxicated groupat $\boldsymbol{p}<0.0001$ (Table 3, Fig. 8.).The treatment with Pomegranate and Pistachio $(100 \mathrm{mg} / \mathrm{kg})$ either in normal or nano forms effectively increased the levels of both GSH and SODp $<0.05$. While levels of LPO and NO showed a prominent reduction upon treatment with both extracts (Table 3, Fig. 8.). While its Nano form of pistachio revealed more powerful as it restored the NO value to 1.58 compared to 3.41 in the challenged TAA group. The TAA-intoxication resulted in a remarkable elevation at $(\boldsymbol{p}<0.05)$ in the measured inflammatory markers as 2 fold and 2.5 fold in IL6 and TNF $\alpha$ consecutively and about 6 fold increase in the levels of AFP as well as $\mathrm{HSP}_{\mathbf{7 0}}$ compared to the TAA intoxicated group (Table 3, Fig. 9.). Treatment with either pomegranate peel and or pistachio normal form extracts markedly reduced AFP, TNF $\alpha$, IL6 and HSP 70 $_{\text {levelsrespectively }}$ with the advantage of pistachio either in normal or Nano forms as it revealed a higher restoration power than pomegranate with the inflammatory markers as seen in Table 3. Therefore, the results provided proof for each of the pomegranates and pistachios, either in their normal or nano forms, showing a different percentage of change as shown in Fig.9 
Table (3) Therapeutic effects of both of pomegranate, pistachio and their nanoparticles on oxidative stress markers and inflammatory cytokines.

\begin{tabular}{|c|c|c|c|c|c|c|}
\hline Groups Parameters & $\begin{array}{c}\text { Control } \\
\text { (-ve) }\end{array}$ & $\begin{array}{r}\text { TAA } \\
(+\mathbf{e})\end{array}$ & $\mathbf{T A A}+\mathbf{P O}$ & TAA+NPO & TAA+PS & TAA+NPS \\
\hline $\begin{array}{c}\text { Glutathione } \\
\text { (ug/mg protein) }\end{array}$ & $\begin{array}{c}48.50^{\mathrm{a}} \\
\pm \\
2.62\end{array}$ & $\begin{array}{c}21.80^{d} \\
\pm \\
3.02\end{array}$ & $\begin{array}{c}42.20^{b} \\
\pm \\
2.40\end{array}$ & $\begin{array}{c}30.43^{\mathrm{c}} \\
\pm \\
1.68\end{array}$ & $\begin{array}{c}31.98^{c} \\
\pm \\
3.06\end{array}$ & $\begin{array}{c}29.97^{c} \\
\pm \\
4.13\end{array}$ \\
\hline $\begin{array}{l}\text { Superoxide dismutase } \\
\text { (Umol/mg protein) }\end{array}$ & $\begin{array}{c}0.123^{\mathrm{a}} \\
\pm \\
\pm \\
0.008\end{array}$ & $\begin{array}{c}0^{0.048} 8^{d} \\
\pm \\
0.004\end{array}$ & $\begin{array}{c}0.065^{c} \\
\pm \\
\pm \\
0.007\end{array}$ & $\begin{array}{c}0.087^{b} \\
\pm \\
0.009\end{array}$ & $\begin{array}{c}0.069^{c} \\
\pm \\
0.006\end{array}$ & $\begin{array}{c}0^{0.083}{ }^{b} \\
\pm \\
0.006\end{array}$ \\
\hline $\begin{array}{l}\text { Lipid Peroxidation } \\
\text { (Umol /mg protein) }\end{array}$ & $\begin{array}{c}1.099^{d} \\
\pm \\
0.086\end{array}$ & $\begin{array}{c}3.45^{\mathrm{a}} \\
\pm \\
\mathbf{0 . 0 8 2}\end{array}$ & $\begin{array}{c}1.77^{\mathrm{b}} \\
\pm \\
0.104\end{array}$ & $\begin{array}{c}1.402^{\mathrm{c}} \\
\pm \\
0.185\end{array}$ & $\begin{array}{c}1.78^{b} \\
\pm \\
0.071\end{array}$ & $\begin{array}{c}1.75^{b} \\
\pm \\
0.14\end{array}$ \\
\hline $\begin{array}{c}\text { Nitric Oxide } \\
\text { (mmol/g tissue) }\end{array}$ & $\begin{array}{c}1.034^{\mathrm{d}} \\
\pm \\
0.18\end{array}$ & $\begin{array}{c}3.41^{\mathrm{a}} \\
\pm \\
0.31\end{array}$ & $\begin{array}{c}1.37^{\mathrm{cd}} \\
\pm \\
0.17\end{array}$ & $\begin{array}{c}1.28^{\mathrm{cd}} \\
\pm \\
0.12\end{array}$ & $\begin{array}{c}2.39^{\mathrm{b}} \\
\pm \\
0.14\end{array}$ & $\begin{array}{c}1.58^{c} \\
\pm \\
0.21\end{array}$ \\
\hline $\begin{array}{c}\text { AFP } \\
(\mathrm{ng} / \mathrm{ml})\end{array}$ & $\begin{array}{c}1.212^{\mathrm{e}} \\
\pm \\
\mathbf{0 . 0 7}\end{array}$ & $\begin{array}{c}7.88^{\mathrm{a}} \\
\pm \\
0.27\end{array}$ & $\begin{array}{c}5.304^{\mathrm{c}} \\
\pm \\
0.19\end{array}$ & $\begin{array}{c}6.26^{\mathrm{b}} \\
\pm \\
0.058\end{array}$ & $\begin{array}{c}5.03^{\mathrm{d}} \\
\pm \\
0.13\end{array}$ & $\begin{array}{c}4.85^{\mathrm{d}} \\
\pm \\
\mathbf{0 . 1 3 5}\end{array}$ \\
\hline $\begin{array}{c}\text { TNF } \\
(\mathbf{P g} / \mathbf{m l})\end{array}$ & $\begin{array}{c}60.58^{\text {f }} \\
\pm \\
0.89\end{array}$ & $\begin{array}{c}159.90^{\mathrm{a}} \\
\pm \\
2.14\end{array}$ & $\begin{array}{c}112.54^{\mathrm{c}} \\
\pm \\
0.855\end{array}$ & $\begin{array}{c}119.7^{\mathrm{b}} \\
\pm \\
0.86\end{array}$ & $\begin{array}{c}106.82^{\mathrm{d}} \\
\pm \\
1.61\end{array}$ & $\begin{array}{c}100.94^{\mathrm{b}} \\
\pm \\
2.08\end{array}$ \\
\hline $\begin{array}{c}\text { IL6 } \\
\text { (Pg/ml) }\end{array}$ & $\begin{array}{c}93.87^{\mathrm{f}} \\
\pm \\
2.39\end{array}$ & $\begin{array}{c}236.77^{\mathrm{a}} \\
\pm \\
9.95\end{array}$ & $\begin{array}{c}165.95^{\mathrm{b}} \\
\pm \\
2.71\end{array}$ & $\begin{array}{c}158.36^{\mathrm{c}} \\
\pm \\
1.89\end{array}$ & $\begin{array}{c}145.67^{\mathrm{d}} \\
\pm \\
3.60\end{array}$ & $\begin{array}{c}135.47^{\mathrm{e}} \\
\pm \\
2.39\end{array}$ \\
\hline $\begin{array}{l}\text { HSP-70 } \\
\text { (PG/mg) }\end{array}$ & $\begin{array}{c}111.75^{\mathrm{f}} \\
\pm \\
4.90\end{array}$ & $\begin{array}{c}791.69^{\mathrm{a}} \\
\pm \\
6.65\end{array}$ & $\begin{array}{c}344.24^{\mathrm{c}} \\
\pm \\
4.95\end{array}$ & $\begin{array}{c}400.34^{b} \\
\pm \\
7.40\end{array}$ & $\begin{array}{c}329.39^{\mathrm{d}} \\
\pm \\
6.56\end{array}$ & $\begin{array}{c}249.78^{\mathrm{e}} \\
\pm \\
4.74\end{array}$ \\
\hline
\end{tabular}

The data are represented as average \pm SD of 10rats in each group. Statistical analysis was conducted using a one-way variance analysis (ANOVA) using the CoStat computer program with the lowest level (LSD) between $\mathrm{p}<0.05$ classes. Groups with the same letters are not significantly different, whereas those with different letters vary considerably atp $<0.05$. 


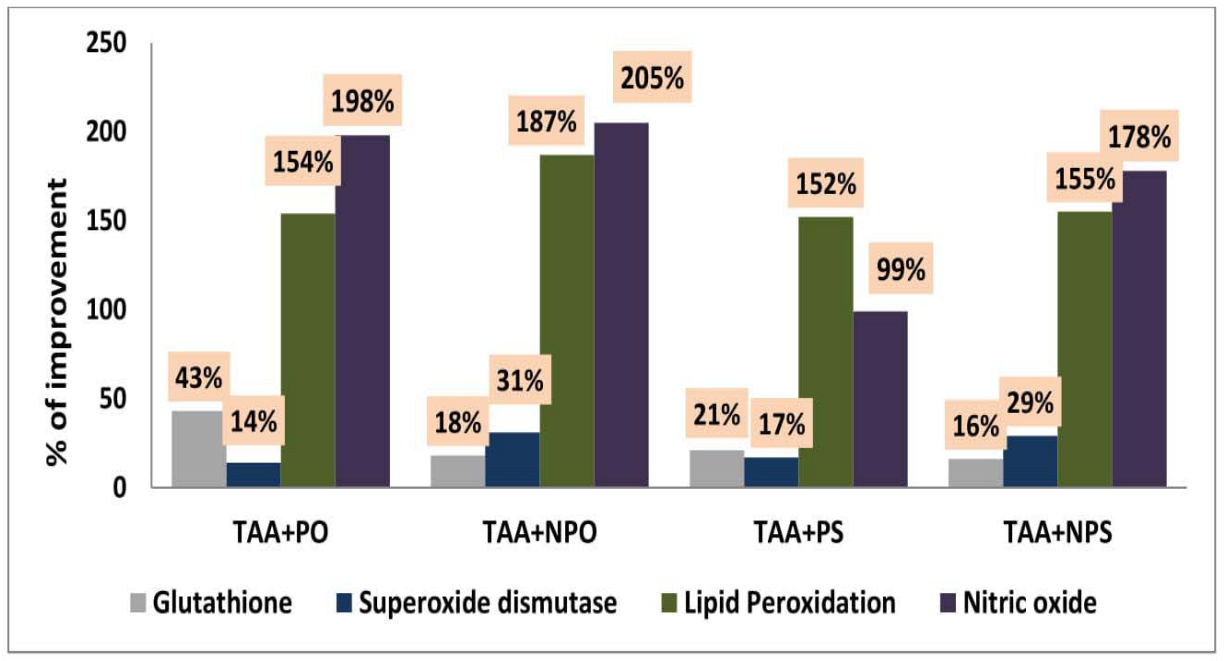

Fig. 8. Therapeutic effects of both of Pomegranate and Pistachio and their nanoparticle forms on oxidative stress markers. *Values are expressed as $\%$ of improvement related to normal control and thioacetamide groups.

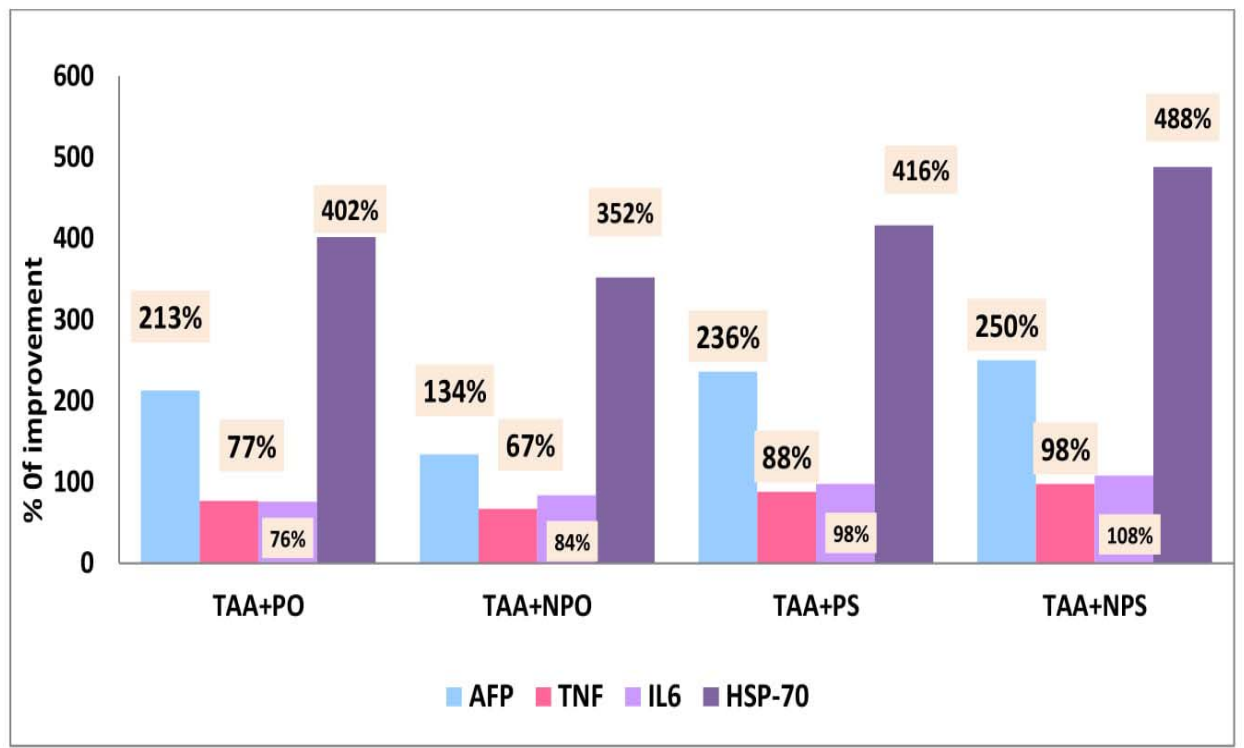

Fig. 9.Therapeutic effects of both of Pomegranate and Pistachio and their nanoparticle forms on inflammatory cytokines. *Values are expressed as \% of improvement related to normal control and thioacetamide groups. 


\subsection{Effect of pomegranate and pistachio in their normal and Nano forms onDNA degradation:}

Comet assay is a sensitive and well-validated technique used to evaluate the fragmentation of DNA, a typical component of toxic DNA damage and apoptosis..Compared to the normal control group, TAA has substantially caused DNA damage. This DNA damage was demonstrated by a significant increase in the comet parameters presented as tail length with different three classes (Fig. 10, 11), Tail and tail moment DNA (percentage); the primary predictive parameter for DNA damage (Table 4).In the hepatotoxic community there was a large broom-like tail and a small comet eye.(Fig. 10, 11). The length of the tail increases as DNA damage increases as seen inFig.10, 11. Whereas, the administration of both pomegranate and pistachio in either their natural or nano forms impaired the TAA effect by substantially reducing the length of the tail; with the dominance of the pomegranate and pistachio nano forms (Table 4, Fig. 12).

Table (4): Therapeutic effects of both of pomegranate and pistachio and their nanoparticles on DNA damaged cells by comet assay.

\begin{tabular}{|c|c|c|c|c|c|c|c|}
\hline \multirow[t]{2}{*}{ Groups } & \multicolumn{2}{|c|}{ cells No. } & \multicolumn{4}{|c|}{ Comet class } & \multirow{2}{*}{$\begin{array}{c}\text { Damaged } \\
\text { DNA cells } \\
\text { (mean } \pm \text { SD) }\end{array}$} \\
\hline & Analyzed & $\begin{array}{c}\text { Total } \\
\text { comets }\end{array}$ & $\mathbf{0}$ & 1 & 2 & 3 & \\
\hline Negative control & 500 & 33 & 467 & 25 & 8 & $\mathbf{0}$ & $6.61 \pm 0.54^{d}$ \\
\hline TAA & 500 & 123 & 377 & 35 & 43 & 45 & $24.64 \pm 1.14^{\mathrm{a}}$ \\
\hline TAA+PO & 500 & 73 & 427 & 28 & 26 & 19 & $14.62 \pm 0.89^{b}$ \\
\hline TAA+NPO & 500 & 51 & 449 & 24 & 17 & 10 & $10.20 \pm 1.3^{c}$ \\
\hline TAA+PS & 500 & 61 & 439 & 21 & 23 & 17 & $12.22 \pm 1.4^{\mathrm{bc}}$ \\
\hline TAA+NPS & 500 & 54 & 446 & 16 & 22 & 16 & $10.81 \pm 0.8^{c}$ \\
\hline
\end{tabular}

Class $0=$ no tail; $1=$ tail length $<$ diameter of nucleus; $2=$ tail length between $1 \mathrm{X}$ and $2 \mathrm{X}$ the diameter of nucleus; and $3=$ tail length $>2 \mathrm{X}$ the diameter of nucleus. $\left(^{*}\right)$ : No of cells analyzed was 100 per an animal. 


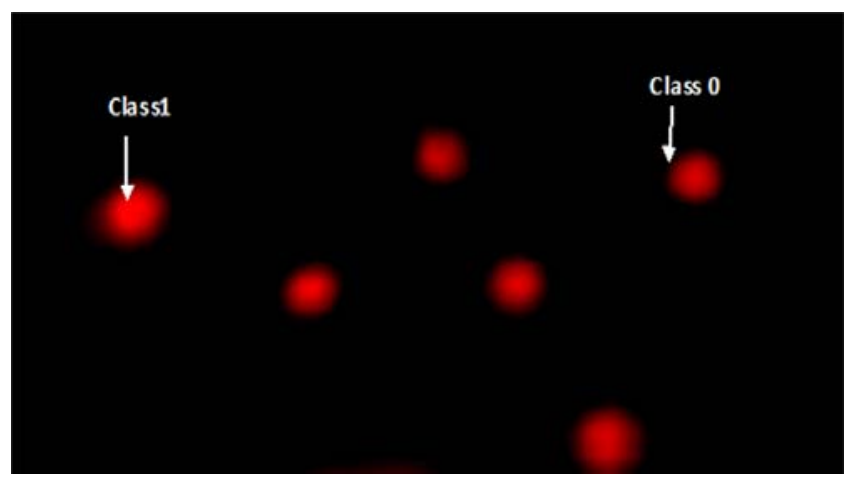

Fig. 10. Visual DNA damage score (class 0 and 1) using comet assay in liver tissues.

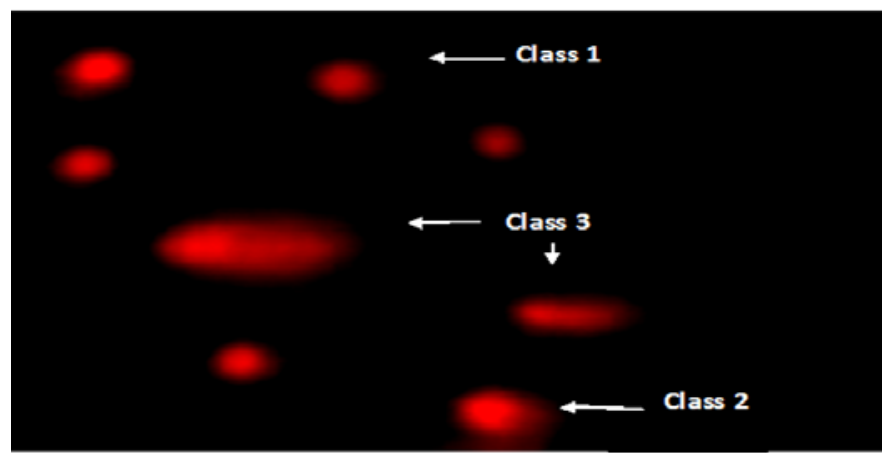

Fig. 11. Visual DNA damage score (classes 2 and 3) using liver tissue comet assay. 
bioRxiv preprint doi: https://doi.org/10.1101/2020.05.06.071001; this version posted May 8, 2020. The copyright holder for this preprint (which was not certified by peer review) is the author/funder, who has granted bioRxiv a license to display the preprint in perpetuity. It is made available under aCC-BY-NC 4.0 International license.

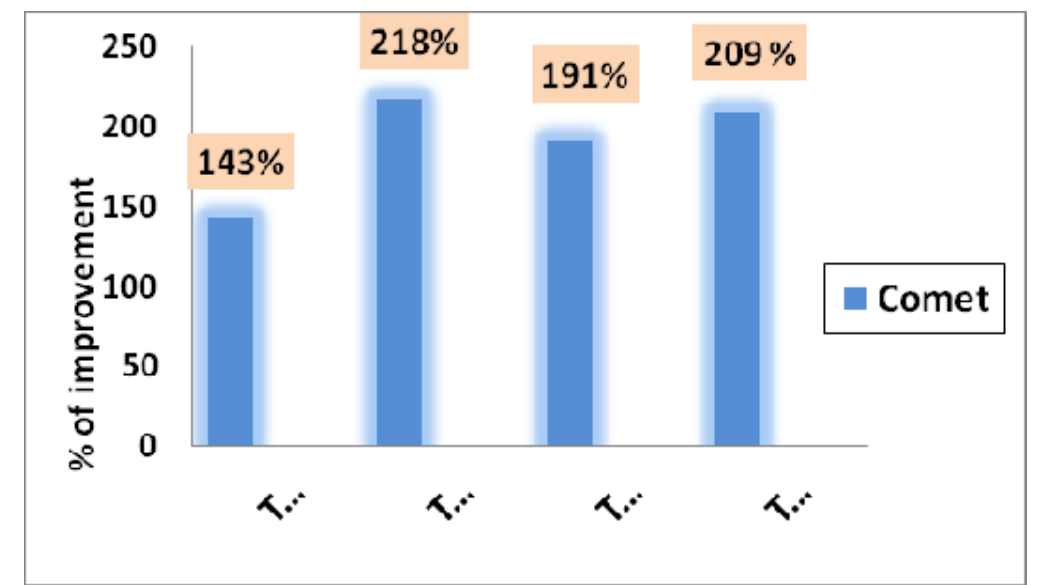

Fig.12: Therapeutic effects of both of Pomegranate and Pistachio and their nanoparticles forms on Comet assay. *Values are expressed as $\%$ of improvement related to normal control and thioacetamide grouns. 


\subsection{Pearson's correlations and ROC-Curve of the parameters in all groups.}

Table 5 shows positivecorrelations between liver functions, lipid profile, oxidative stress markers and inflammatory cytokines at different correlation levels expect for GSH and SOD activity.Table 6 shows area under the curve AUC equal 1 and showed the same sensitivity and specificity values for virtually every biomarker.

Table (5) Pearson's correlations between liver function, lipid profile, oxidative markers and inflammatory cytokines.

\begin{tabular}{|c|c|c|c|c|}
\hline $\begin{array}{c}\mathbf{R} \\
\text { (Person Correlation) }\end{array}$ & AFP & TNFa & IL6 & HSP70 \\
\hline ALT & $0.621 * *$ & $0.735 * *$ & $0.773 * *$ & $0.849 * *$ \\
\hline AST & $0.857 * *$ & $0.905 * *$ & $0.889 * *$ & $0.928 * *$ \\
\hline ALP & $0.694 * *$ & $0.778 * *$ & $0.801 * *$ & $0.863 * *$ \\
\hline TG & $0.733 * *$ & $0.713 * *$ & $0.643 * *$ & $0.653 * *$ \\
\hline TC & $0.571 * *$ & $0.714 * *$ & $0.835^{* *}$ & $0.816^{* *}$ \\
\hline $\mathbf{T P}$ & $0.763^{* *}$ & $0.821 * *$ & $0.805^{* *}$ & $0.858 * *$ \\
\hline TB & $0.513^{* *}$ & $0.398 * *$ & 0.263 & 0.244 \\
\hline GSH & $-0.804 * *$ & $-0.786 * *$ & $-0.684 * *$ & $-0.734 * *$ \\
\hline SOD & $-0.854 * *$ & $-0.885^{* *}$ & $-0.873 * *$ & $-0.830 * *$ \\
\hline MDA & $0.759 * *$ & $0.862 * *$ & $0.916 * *$ & $0.924 * *$ \\
\hline NO & $0.680 * *$ & $0.768^{* *}$ & $0.804^{* *}$ & $0.832 * *$ \\
\hline AFP & 1 & $0.977 * *$ & $0.979 * *$ & $0.886^{* *}$ \\
\hline TNFa & $0.977 * *$ & 1 & $0.773^{* *}$ & $0.849 * *$ \\
\hline IL6 & $0.921 * *$ & $0.979 * *$ & 1 & $0.928 * *$ \\
\hline HSP70 & $0.886^{* *}$ & $0.961 * *$ & $0.979 * *$ & 1 \\
\hline
\end{tabular}

* TheCorrelation is significant at the level of $0.05 * *$ The correlation is significant at the level of 0.01 . 
Table 6: Sensitivity \& specificity of the measured parameters in all groups (ROC- curve)

\begin{tabular}{|c|c|c|c|c|c|c|c|}
\hline Parameters & Groups & $\mathbf{A U C}$ & $\begin{array}{c}\text { Cut-off } \\
\text { value }\end{array}$ & $\begin{array}{c}\text { Sensitivity } \\
\%\end{array}$ & $\begin{array}{c}\text { Specificity } \\
\%\end{array}$ & $P$ value & $95 \%$ CI \\
\hline \multirow{4}{*}{ AFP } & TAA+ PO & 1.000 & 6.555 & $100.0 \%$ & $100.0 \%$ & 0.009 & $\begin{array}{l}1.000- \\
1.000\end{array}$ \\
\hline & TAA + NPO & 1.000 & 6.930 & $100.0 \%$ & $100.0 \%$ & 0.009 & $\begin{array}{l}1.000- \\
1.000\end{array}$ \\
\hline & TAA+PS & 1.000 & 6.355 & $100.0 \%$ & $100.0 \%$ & 0.009 & $\begin{array}{l}1.000- \\
1.000\end{array}$ \\
\hline & TAA + NPS & 1.000 & 6.280 & $100.0 \%$ & $100.0 \%$ & 0.009 & $\begin{array}{l}1.000- \\
1.000\end{array}$ \\
\hline \multirow{4}{*}{ TNF $\alpha$} & TAA $+\mathbf{P O}$ & 1.000 & 135.070 & $100.0 \%$ & $100.0 \%$ & 0.009 & $\begin{array}{l}1.000- \\
1.000\end{array}$ \\
\hline & $\mathbf{T A A}+\mathbf{N P O}$ & 1.000 & 138.770 & $100.0 \%$ & $100.0 \%$ & 0.009 & $\begin{array}{l}1.000- \\
1.000\end{array}$ \\
\hline & TAA+PS & 1.000 & 132.885 & $100.0 \%$ & $100.0 \%$ & 0.009 & $\begin{array}{l}1.000- \\
1.000\end{array}$ \\
\hline & TAA+NPS & 1.000 & 130.075 & $100.0 \%$ & $100.0 \%$ & 0.009 & $\begin{array}{l}1.000- \\
1.000\end{array}$ \\
\hline \multirow{4}{*}{ IL6 } & $\mathbf{T A A}+\mathbf{P O}$ & 1.000 & 196.930 & $100.0 \%$ & $100.0 \%$ & 0.009 & $\begin{array}{l}1.000- \\
1.000\end{array}$ \\
\hline & TAA+NPO & 1.000 & 192.835 & $100.0 \%$ & $100.0 \%$ & 0.009 & $\begin{array}{l}1.000- \\
1.000\end{array}$ \\
\hline & TAA+PS & 1.000 & 187.925 & $100.0 \%$ & $100.0 \%$ & 0.009 & $\begin{array}{l}1.000- \\
1.000\end{array}$ \\
\hline & TAA+NPS & 1.000 & 182.290 & $100.0 \%$ & $100.0 \%$ & 0.009 & $\begin{array}{l}1.000- \\
1.000\end{array}$ \\
\hline \multirow{4}{*}{ HSP70 } & TAA $+\mathbf{P O}$ & 1.000 & 567.575 & $100.0 \%$ & $100.0 \%$ & 0.009 & $\begin{array}{l}1.000- \\
1.000\end{array}$ \\
\hline & TAA+NPO & 1.000 & 596.535 & $100.0 \%$ & $100.0 \%$ & 0.009 & $\begin{array}{l}1.000- \\
1.000\end{array}$ \\
\hline & TAA+PS & 1.000 & 561.165 & $100.0 \%$ & $100.0 \%$ & 0.009 & $\begin{array}{l}1.000- \\
1.000\end{array}$ \\
\hline & TAA+NPS & 1.000 & 520.700 & $100.0 \%$ & $100.0 \%$ & 0.009 & $\begin{array}{l}1.000- \\
1.000\end{array}$ \\
\hline
\end{tabular}




\subsection{Histopathologic examination}

Histopathological analysis of the representative liver tissues of the control group showed normal morphology, hepatocyte structure and central vein. (Fig. 13.A). TAA-intoxicated group Displayed Focal inflammatory cell infiltration in the hepatic parenchyma covering the central dilated veinFig. 13. B, with diffuse spread of kupfer cells between hepatocytes. Pomegranate and /pistachio treatment (100 $\mathrm{mg} / \mathrm{kg}$ ) either in normal or nano forms have shown observable healing effect presented as shown in (Fig. 13.C, D, E, F) with only some degenerative changes. 


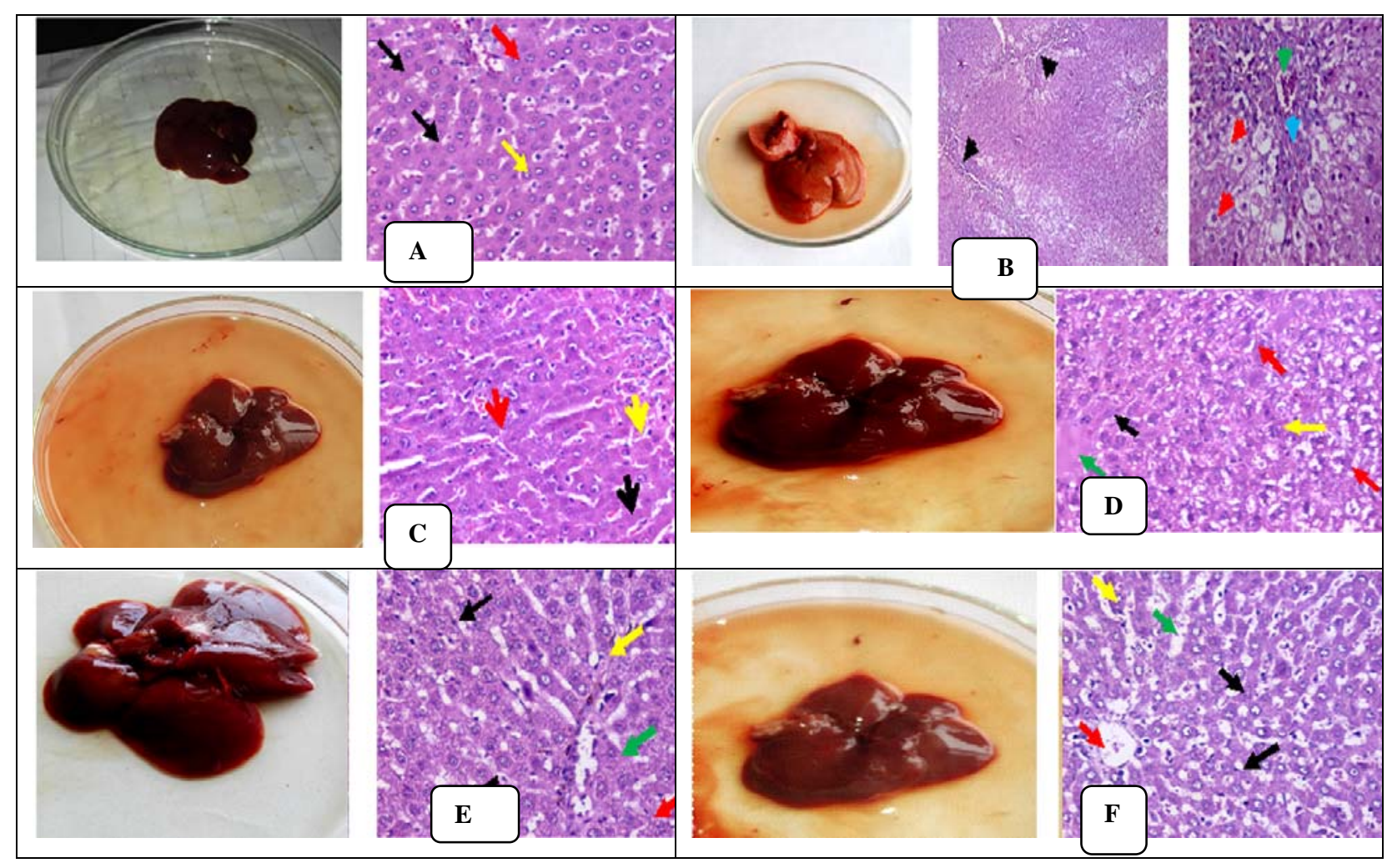

Fig. 13. A. The liver portion of the normal control group (standard control) showed typical structure and morphology of the liver tissue, thin-plated hepatocytes (black arrow) and sinusoids (yellow arrow), central red vein. (H\&E, x200, x400). B. Liver section from animal with TTA group showed partial distortion of lobular hepatic architecture (black arrow), with moderate hydropic degeneration of hepatocyte (red arrow) and binucleated hepatocytes (yellow arrow), portal tract with vein congestion (green arrow) thick fibrous tissue in portal tract (blue arrow) (H\&E,x200, x40). C. liver section of animal treated with pomegranate group displayed Hepatocytes arranged in thin plates (black arrow) and congested central vein (red arrow) with a preserved architecture, moderately dilated and congested sinusoids (yellow arrow) (H\&E, x200, x400). D. Liver section of animal treated Nano pomegranate group showed intact lobular hepatic architecture, hepatocyte with thin plates (black arrow). Moderate hydropic degeneration (red arrow) and binucleated hepatocytes (yellow arrow), central vein (green arrow) (H\&E, x200, x400). E. The liver section of the animal treated with Pistachio extract showed hepatic tissue intact lobular hepatic structure and architecture, hepatocytes arranged in thin plates with mild hydropic changes (black arrow) and congested central vein (red arrow) binucleated hepatocytes (yellow arrow), slightly dilated and congested sinusoids(green arrow) (H\&E, x200, x400). F. liver section of animal treated with Nano Pistachio group showed Hepatic tissue with nearly normal structure and architecture, hepatocytes arranged in thin plates (black arrow) and congested central vein (red arrow) binucleated hepatocytes (yellow arrow),, mildly dilated and congested sinusoids (green arrow) (H\&E, x200, x400). 


\subsection{Effect of pomegranate / pistachio either in their normal and/or their Nano forms on} the inflammatory markers by immunohistochemistry.

The anti-inflammatory effect of pomegranate /pistachio either in normal and/or its nano forms was further evaluated viaimmunohistochemistry expression of pro inflammatory markers, IL-6 TNF $\alpha$ in hepatic tissues (Fig. 14 A - L). TAA intoxication $350 \mathrm{mg} / \mathrm{kg}$ resulted in a substantial elevation in IL-6 and TNF- $\alpha$ expression compared to normal control group (Fig. 14, A, G) respectively that was located mostly in cytoplasm of hepatocytes in portal tract and fibrous septa .Treatment with pomegranate/and or pistachio either in their normal or Nano forms improved and down regulated the expression of both IL6 (Fig.14, B- F) and TNF- $\boldsymbol{\alpha}$ (Fig.14, I - L) respectively, with the notion has been shown that pomegranate/pistachio in its nano forms is more likely to inhibit TAA induced inflammatory response compared to positive control (Fig.14. B - L). 


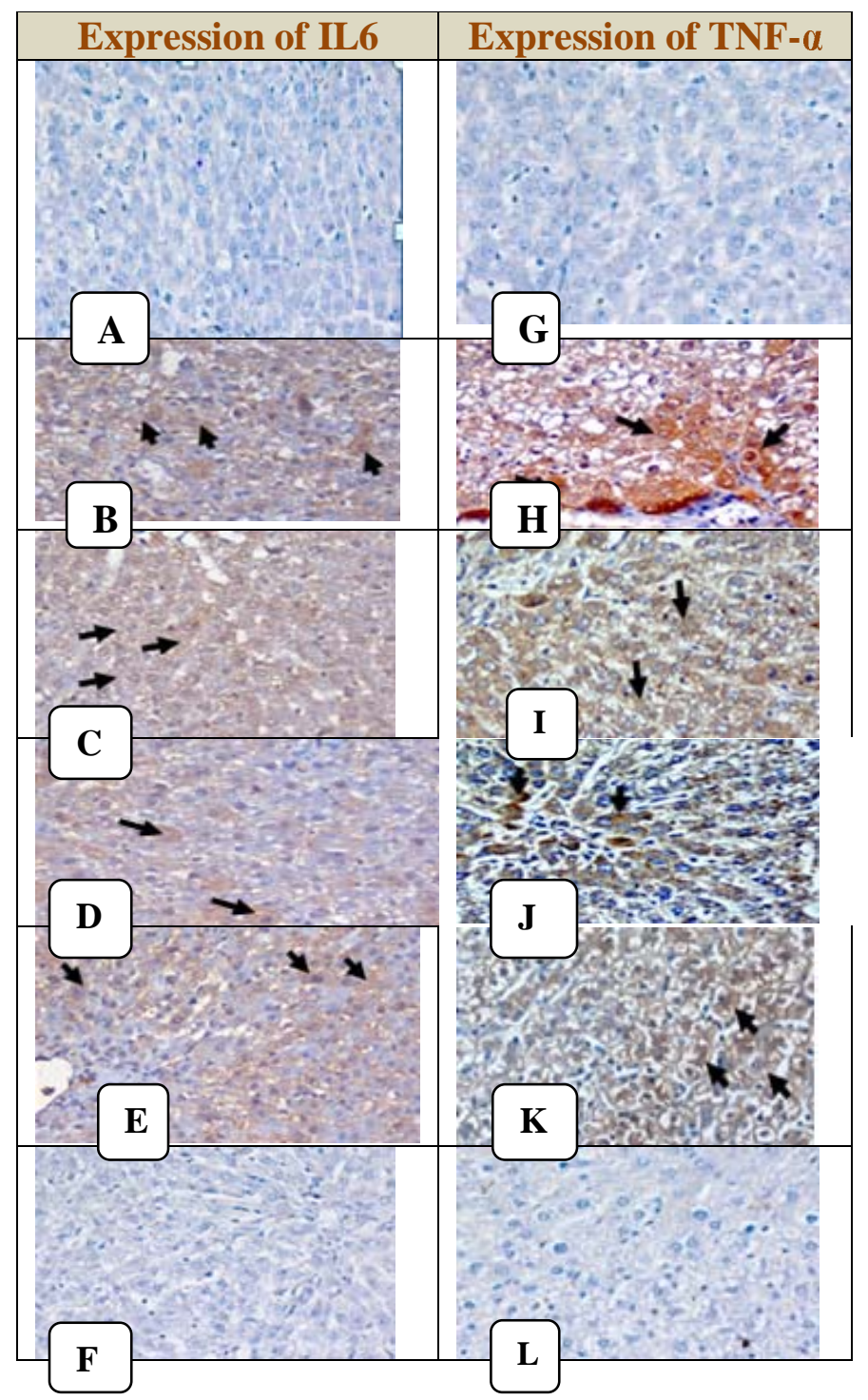

Fig. 14:A.liver section from normal control group showed negative expression of IL6 ( DAB,IHC, x400).B.liver section from positive control group showed moderate expression of IL6 as brownish cytoplasmic stain of hepatocytes in about $60 \%$ (black arrow)( DAB,IHC, x400). C.liver section from animal treated with pomegranate group showed moderate expression of IL6 as brownish cytoplasmic stain of hepatocytes in about $40 \%$ (black arrow)( DAB,IHC, x400).D.liver section from animal treated Nano pomegranate group showed moderate expression of IL6 as brownish cytoplasmic stain of hepatocytes in about $10 \%$ (black arrow)( DAB,IHC, x400).E.liver section from animal treated Pistachio group showed mild expression of IL6 as brownish cytoplasmic stain of hepatocytes in about $25 \%$ (black arrow)( DAB,IHC, x400).

F.liver section from animal treated Nano Pistachio group showed negative expression of IL6 (DAB, IHC, x400).

G.liver section from normal control group showed negative expression of TNF $\alpha$ ( DAB,IHC, x400).H.liver section from positive control group showed marked expression of TNF $\alpha$ as brownish cytoplasmic stain of hepatocytes in about $70 \%$ (black arrow)( DAB,IHC, x400).I.liver section from animal treated with pomegranate group showed moderate expression of TNF $\alpha$ as brownish cytoplasmic stain of hepatocytes in about $40 \%$ (black arrow)( DAB,IHC, x400).J.liver section from animal treated Nano pomegranate group showed moderate expression of TNF $\alpha$ as brownish cytoplasmic stain of hepatocytes in about $10 \%$ (black arrow)( DAB,IHC, x400).K.liver section from animal treated Pistachio group showed moderate expression of TNF $\alpha$ as brownish cytoplasmic stain of hepatocytes in about $30 \%$ (black arrow)( DAB,IHC, x400).L.liver section from animal treated Nano Pistachio group showed negative expression of TNF $\alpha$ (DAB, IHC, x400).

\section{Discussion:}

Oxidative stress appears to play a major role in the outbreak and progression of wide array of diseases, including the liver ${ }^{[49]}$. TAA has been recognized as hepatotoxic compound in different studies ${ }^{[50]}$. As it transforms into thioacetamide sulfoxide (TAAS) along the pathway-dependent cytochrome P-450 (CYP) and/or flavin-containing monooxygenase systems forming TAA 
sulfoxide involving TAA-S, S-dioxide that begin to form lipid peroxidation at the plasma membrane level ${ }^{\left[\mathbf{5 1}^{1}, \mathbf{5 2}\right]}$. Binding of these metabolites to liver macromolecules dramatically inspire a reactive oxygen species moiety which in turn induce an acute centrilobular liver necrosis and consequently leads to liver diseases and further can overwhelm the body antioxidant defense mechanisms reaching to vital ingredients ending up to damage the DNA ${ }^{[12]}$. Emerging research evidence indicates that natural compounds / plants have shown beneficial effects of antioxidants in the defense of the liver against TAA-induced injury ${ }^{[53]}$ and can improve immune function ${ }^{[54]}$ either in normal or in nano-form ${ }^{[55] .}$

In accordance with this assumption, the results of this study demonstrated the efficacy of the nanoparticles synthesized from the natural product as an excellent capping and reducing agent capable of producing pomegranate and pistachio nano particles [P. GranatumL] [ pistashiaatlantica] aqueous nano-extracts with average spherical size ranging from 7-17 $\mathrm{nm}$. The present study showed that TAA-intoxication in a single dose $350 \mathrm{mg} / \mathrm{bw}$ had superabundant hepatotoxic symptoms clearly represented via the elevation in liver enzymes (AST, ALT and ALP), lipid profiles (TP, TC and TG) as well as total bilirubin (Table.2). This observation was close to Fontana et al ${ }^{[56]}$ and $\mathrm{Al}$ shawsh et $\mathrm{al}^{[57]}$ findings as they demonstrated that TAA has been shown to interfere with the continuous movement of RNA from the nucleus to the cytoplasm, may cause membrane injury resulting in elevation and release of serum markers of the liver ${ }^{[58]}$. Such leakage of the enzymes into the blood was accompanied in our study with partial distortion of lobular hepatic architecture, with moderate hydropic degeneration of hepatocyte and binucleated hepatocytes, portal tract with vein congestion thick fibrous tissue in portal tract in addition to inflammatory infiltration of the liver which revealed severe liver injury (Table 2, Fig13B). Interestingly, our findings demonstrated an obvious amelioration and improvement in all parameters when treated with pomegranate peel extract and /or pistachio either in normal or nano forms as indicated by reduction or normalization of the levels of aminotransferases, alkaline phosphatase, lipid profile, total bilirubin (Table 2, Fig. 6, 7).These improvements extends to liver architecture (Fig 13C-F). These observations are most likely attributed to the presence of hydrolysable polyphenols, specifically ellagitannins, which were considered to be the most active antioxidants among the tannins contained therein. These compounds (elagic acid, punicalagin, punicalin and galagid acid) have been shown to have 
increased antioxidant and pleiotropic effects and are believed to act in synergy ${ }^{[59,60]}$. Our findings were found to be similar to studies of Husain et al ${ }^{[61]}$, Bachoual et $\mathrm{al}^{[62]}$ and seem to be compatible with Esmaillzadeh et $\mathrm{al}^{[63]}$ as they demonstrated that pomegranate juice significantly reduce the total cholesterol level. The results also go in consistent with Al-Shaaibi et al ${ }^{[64]}$ as they mentioned that administration of Pomegranate peel extract ameliorate liver enzymes, control lipogenesis and improve the histologic image of liver. And in agreement with Kocyigit et $\left.\mathrm{al}^{[65}\right]$, Sheridan et $\mathrm{al}^{[66]}$; Kay et $\mathrm{al}^{[67]}$ as they demonstrated that pistachio has a beneficial effect on the improvementof aminotransferase levels and blood lipid profile, This can be attributed to the existence of ellagitannins hydrolysable polyphenols as a highly antioxidant compounds, similar to that in pomegranate.In addition to other antioxidants that can effectively play a key role in stopping oxidative reactions in chains such as fatty acids, flavonoids and phenolic compounds. ${ }^{[32,}$ ${ }^{33]}$ tocopherols, carotenes, lutein, selenium and phytoestrogens ${ }^{[68,69] .}$

In another observation, both nano forms of pomo and pistachio treated groups showed significant increase levels of bilirubin. The increased levels was further describes nano forms of pistachio as a protective polyphenols. These findings appear to be consistent with previous data related to Bilirubin IX $\alpha$ as it recognized as a potent antioxidant by Vitek et al ${ }^{[70]}$. While bilirubin is toxic in children, it is considered for health promotion in adults. At the same time, according to some clinical literature, moderately elevated serum bilirubin levels were generally correlated with decreased incidence of chronic diseases ${ }^{[71]}$.

A pronounced increment in lipid peroxidation and NO levels were recorded in hepatic homogenate. These results were concomitant with a pronounced, significant reduction in hepatic - GSH and SOD levels. The results can be delegated to the thiono-sulfur compound of TAA as a hepatotoxic which induce hepatic damage and act as an initiator for a series of severe inflammatory changes via generation of ROS and down regulator of the antioxidant defense mechanism ${ }^{[72]}$. Moreover In liver disease L-arginine-NO pathway is activated, and lead to the formation of nitric oxide, the mater which can explain the significant increase in nitric oxide level upon intoxication by TAA ${ }^{[73]}$ (Table 3).

Interestingly, the great significant reduction effect on the lipid peroxidation level as well as nitric oxide synchronized with increment in glutathione and SOD levels were taken by the nano 
forms of each of pomegranate \& pistachio extracts respectively as they proved to be more superior compared to their normal form (Table 3, Fig. 8). The improvement registered in the measured redox parameters may be in agreement with what previously reported that Stimulation of the Nrf2/ARE pathway is necessary for antioxidant defense enzyme induction and intracellular GSH modulation in response to stress ${ }^{[74]}$ (Table 3). These nano form results can be interpreted upon their Benign nature and the presence of essential functional groups make AgNPs very stable and prevent nanoparticles from being anchored.In addition, the existence of the bioactive molecules on the surface of AgNPs may increase its efficacy and bioavailability .It can also enhance its solubility, improve plasma half-life, preventing degradation in the intestinal environment and increasing permeation in the small intestine which may confer strong antioxidative activity ${ }^{[75]}$.

Our findings are further consistent with the previous study that pomegranate peel extract had the highest free radical scavenging capacity among the medicinal plants tested and not only juice and oil seed ${ }^{[76,77]}$. And another study for Alturfan et al ${ }^{[78]}$ demonstrated that pistachio consumption can provide antioxidant protection.

In the current study and following treatment with TAA high plasma levels of AFP, TNF- $\alpha$, IL6, and HSP70 were observed in serum as well as in tissue (Table 3, fig. 9). These results may really meet the fact that alteration in the redox status would stimulate the entire inflammatory cascade including the activation of a series of transcription factors ${ }^{[79,80,81]}$. AFP is regarded as a biomarker of proliferating liver stem cells under conditions of liver injury ${ }^{\left[\mathbf{8 2}^{2}\right]}$ Our data showed a marked increase in AFP's post-TAA liver content by about 6 fold compared to [1.2ng/ml] in normal group (Table 3), nano pistachio was in front of its normal and other pomo forms to attenuate and improve the AFP over-production and protect its normal transcription levels in liver, This may explain the mechanism by which nano pistachio worked to prevent its abnormal expression by binding to the enhancer region of the AFP gene. It also may encourage the fetal hepatocyte to start to regenerate. This observation is in accordance with Hessin et al ${ }^{[83]}$ who demonstrated that Pistachio has the ability to modulate the alpha fetoprotein transcriptional levels. 
TNF- $\alpha$ is a community of cytotoxic pro-inflammatory cytokines, believed to play a vital role in liver damage initiation ${ }^{[\mathbf{8 4}]}$. Increased circulating TNF- $\alpha$ activates cell surface TNF- $\alpha$ receptors, resulting in activation of the stress-related protein kinases JNK and IKK $\beta$, leading to increased development of additional inflammatory cytokines such as IL6. TNF reduction is considered a treatment to reduce damage to the liver ${ }^{[85]}$. Surprisingly attenuation of the TAA-induced up regulation of the cytokines TNF $\alpha$, IL6 together was achieved by pomegranate and pistachio either in normal or in nano forms. These data seem to be parallel with coursodonboydle ${ }^{[86]}$ who reported that increased levels of proinflammatory cytokine IL 6 in rat ileum model necrotizing enterocolitis have been normalized after POM seed oil treatment and also go in accordance with the reports of Grace et al ${ }^{[87]}$ and Paternitiet al ${ }^{[88]}$, where the first revealed that Pistachio extract significantly reduced the non-mitochondrial oxidative burst in macrophages associated with inflammatory response. While the other attributed the decrease in TNF- $\alpha$ and Interleukins production to the presence of polyphenols in pistachios which possess antioxidant and antiinflammatory properties. These data were demonstrated immunohistochemicaly in Fig.14, AL.

On the other hand Heat-shock proteins (HSPs) are unique proteins that are synthesized rapidly in cells in response to different kinds of stress, and acting as intracellular protein repair ${ }^{\text {[89] }}$ A marked increase in HSP70 level was recorded following the single injection of TAA to be online with Kuramochi et al ${ }^{[90]}$ who demonstrated that mRNA expressions of HSP 70 tended to be increased with injection of TAA. However, in our study down regulation of HSP70 expression level was achieved by each extracts (Pomo and Pistachio) by different percentages (Table 3, fig.9), but again pistachio extract in its nano form was the most powerful as an anti-inflammatory compared to pomegranate. This is may be interpreted upon the powerful flavonoids beside other phenolic compounds benzoic acid, and hydroxycinnamic acid derivatives, that have antioxidant properties exist in the nano pistachio to induce strong HSP70 immunoreactivity, prevent protein denaturation and succeeded to overcome TAA induced liver damage ${ }^{\text {[91, 92] }}$. These data are parallel to what previously reported by Ibrahim et al. ${ }^{[93]}$ who demonstrated that POM has the ability to prevent protein denaturation, as a way to combat hepatic oxidative stress caused by $\mathrm{CCl} 4$ and also when he attributed the suppression of heat shock protein 70 and inducible nitric oxide synthase 3-nitrotyrosine to pomegranate emulsions ${ }^{[94]}$. 
Moreover, the current data demonstrated an excessive amount of ROS after surpassing various endogenous anti-oxidative defensive mechanisms oxidized the DNA biomolecules (Fig10, 11). Our finding was in agreement with Afifi et al ${ }^{[95]}$,Zargar et al ${ }^{[15]}$ who found a rise in hepatocyte DNA fragmentation following injection of TAA which may be attributed to the increase in cell death via both apoptosis and necrosis ${ }^{[96]}$. However treatment with pomegranate and /or pistachio either in normal or Nano forms as antioxidants were significantly improved and increased DNA resistance to oxidant damage with the superiority of the Nano forms of both plant extracts ( Table 4, fig.12) . The current results may be in consistence with that study of Ahmed et al ${ }^{[97]}$ as he revealed that pomegranate extract with its strong antioxidants, antiinflammatory, anti-apoptotic and ATP-replenishing was able to protect rats from DNA damage. Same data was confirmed by Majidinia et al ${ }^{[98]}$ as he proved polyphenols rich green extracts which is the main constituent of Pistachio leaves and Pomegranate peel as the main effector in decreasing the ROS level and DNA fragmentation, Eventually, the authors verified the findings by positive correlations between the entire markers measured (Table 5) Specificity \& sensitivity for all markers were further determined by Roc curve and the region under the curve was shown to be equal to 1 (Table 6) which concluded that the measured parameters are good markers in case of acute liver failure.

\section{Conclusion:}

Our findings indicated the potential and beneficial role of either pomegranate or pistachio in their normal forms in general and/or in their nano particles in particular, improving the deleterious effects of TAA oxidative stress-mediated damage and reinforcing the antioxidant defense mechanism through its rich antioxidant and anti-inflammatory properties material. Moreover it also reflects the potential of plant extracts to integrate biomolecules that serve as both a reduction and stabilization agents for producing stable and shape-controlled AgNPs with effective medicinal benefits that could contribute to the development of new drugs for acute liver disease. 


\section{Acknowledgement:}

Authors gratefully acknowledge the assistance and any academic help they provided during this study.

Financial support and sponsorship: This study was not financially supported by any source.

\section{Conflicts of interest:}

The authors declare no potential conflicts of interests.

\section{Reference:-}

1. Wang T, Men R, Hu M, Fan X, Yang X, Huang X, and Yang L. Protective effects of Punicagranatum (pomegranate) peel extract on concanavalin A-induced autoimmune hepatitis in mice. Biomedicine \& Pharmacotherapy. 2018; 100, 213-220.

2.Wu, Y L, Feng X C, Lian L H, Jiang Y Z and Nan J X. The protective effects of total saponins from Ornithogalum saundersiae (Liliaceae) on acute hepatic failure induced by lipopolysaccharide and d-galactosamine in mice. Journal of ethnopharmacology.2010; 132(2), 450-455.

3. Lee W M, Stravitz R T and Larson AM. Introduction to the revised American Association for the Study of Liver Diseases Position Paper on acute liver failure. Hepatology. 2012; 55(3), 965-967.

4. Tritto G, Davies, N A and Jalan R. Liver replacement therapy. In Seminars in respiratory and critical care medicine. 2012; (Vol. 33, No. 01, pp. 70-79). Theme Medical Publishers.

5. Wlodzimirow K A, Eslami S, Abu $\square$ Hanna A, Nieuwoudt $M$ and Chamuleau $R$ A F M. Systematic review: acute liver failure-one disease, more than 40 definitions. Alimentary pharmacology \& therapeutics2012; 35(11), 1245-1256.

6. Bernal W and Wendon J. Acute liver failure. New England Journal of Medicine. 2013; $369(26), 2525-2534$.

7. Bonavita AG, Quaresma, K, Cotta $\square$ de $\square$ Almeida V, Pinto M A, Saraiva R M and Alves L A. Hepatocyte xenotransplantation for treating liver disease. Xenotransplantation. 2010; 17(3), 181-187.

8.Yu Y, Fisher J E, Lillegard JB, Rodysill B, Amiot B and Nyberg S L. Cell therapies for liver diseases. Liver transplantation. 2012; 18(1), 9-21. 
9. Bañares, R., Catalina, M. V., and Vaquero, J. (2013). Liver support systems: will they ever reach prime time?.Current gastroenterology reports, 15(3), 312.

10.Butterworth RF, Norenberg MD, Felipo V, Ferenci P, Albrecht J, Blei AT, ISHEN Commission on Experimental Models of HE]. Experimental models of hepatic encephalopathy: ISHEN guidelines. Liver International. 2009 Jul; 29(6):783-788.

11. Tuñón MJ, Alvarez M, Culebras JM, González-Gallego J. An overview of animal models for investigating the pathogenesis and therapeutic strategies in acute hepatic failure. World journal of gastroenterology: WJG. 2009 Jul 7;15(25):3086.

12.Koen YM, Sarma D, Hajovsky H, Galeva NA, Williams TD, Staudinger JL, Hanzlik RP. Protein targets of thioacetamide metabolites in rat hepatocytes. Chemical research in toxicology. 2013 Mar 20;26(4):564-574.

13.Cheng D, Xu W, Yuan L, Zhang X. Investigation of drug-induced hepatotoxicity and its remediation pathway with reaction-based fluorescent probes. Analytical chemistry. $2017 \mathrm{Jul}$ 6;89(14):7693-7700.

14. Quintanilha LF, Takami T, Hirose Y, Fujisawa K, Murata Y, Yamamoto N, Goldenberg RC, Terai S, Sakaida I. Canine mesenchymal stem cells show antioxidant properties against thioacetamide $\square$ induced liver injury in vitro and in vivo. Hepatology Research. 2014 Oct;44(10):E206-217.

15. Zargar S, Wani TA, Alamro AA, Ganaie MA. Amelioration of thioacetamide-induced liver toxicity in Wistar rats by rutin. International journal of immunopathology and pharmacology. 2017 Sep;30(3):207-214.

16.Hassan SA., El sherbiny M., hashim A N., The remarkable- role of Rosemary \&Tamarixaphyllaagainst radiation based therapy. Int J Pharma Bio Sci Oct 8; (4): (B) 292-301(2017).•

17. Okaiyeto K, Nwodo UU, Mabinya LV, Okoh AI. A review on some medicinal plants with hepatoprotective effects. Pharmacognosy Reviews. 2018 Feb 1;12(24):186.

18. Pandey KB, Rizvi SI. Plant polyphenols as dietary antioxidants in human health and disease. Oxidative medicine and cellular longevity. 2009;2(5):270-278.

19. Miguel MG, Neves MA, Antunes MD. Pomegranate (Punicagranatum L.): A medicinal plant with myriad biological properties-A short review. Journal of Medicinal Plants Research. 2010;4(25):2836-2847.

20. Fadavi A, Barzegar M, Azizi MH, Bayat M. Note. Physicochemical composition of ten pomegranate cultivars (Punicagranatum L.) grown in Iran. Food Science and Technology International. 2005 Apr;11(2):113-119. 
21. Lansky EP, Newman RA.Punicagranatum (pomegranate) and its potential for prevention and treatment of inflammation and cancer. Journal of ethnopharmacology. 2007 Jan 19;109(2):177-206.

22.Celik I, Temur A, Isik I.Hepatoprotective role and antioxidant capacity of pomegranate (Punicagranatum) flowers infusion against trichloroacetic acid-exposed in rats. Food and Chemical Toxicology. 2009 Jan 1;47(1):145-149.

23.Banihani S, Swedan S, Alguraan Z. Pomegranate and type 2 diabetes. Nutrition research. 2013 May 1;33(5):341-348.

24. Ismail T, Sestili P \& Akhtar S. Pomegranate peel and fruit extracts: a review of potential anti-inflammatory and anti-infective effects. Journal of ethnopharmacology, (2012). 143(2), 397-405.

25. Wei X, Li S, Li T, Liu L, Liu Y, Wang H \& Zhao M. Pomegranate peel extract ameliorates liver fibrosis induced by carbon tetrachloride in rats through suppressing p38MAPK/Nrf2 pathway. Journal of Functional Foods, (2019)103712.

26. Shaban NZ, El-Kersh MA, El-Rashidy FH, Habashy NH. Protective role of Punicagranatum (pomegranate) peel and seed oil extracts on diethylnitrosamine and phenobarbital-induced hepatic injury in male rats. Food chemistry. 2013 Dec 1;141(3):15871596.

27. Sharma P, McClees S, Afaq F. Pomegranate for prevention and treatment of cancer: an update. Molecules. 2017;22(1):177.

28. Sorrenti V, Randazzo CL, Caggia C, Ballistreri G, Romeo FV, Fabroni S, Timpanaro N, Raffaele M, Vanella L. Beneficial Effects of Pomegranate Peel Extract and Probiotics on Pre-adipocyte Differentiation. Frontiers in microbiology. 2019;10,660.

29. Bozorgi M, Memariani Z, Mobli M, SalehiSurmaghi MH, Shams-Ardekani MR, Rahimi R. Five Pistacia species (P. vera, P. atlantica, P. terebinthus, P. khinjuk, and P. lentiscus): a review of their traditional uses, phytochemistry, and pharmacology. The Scientific World Journal. 2013; 2013.

30. Bhouri W, Derbel S, Skandrani I, Boubaker J, Bouhlel I, Sghaier MB, Kilani S, Mariotte AM, Dijoux-Franca MG, Ghedira K, Chekir-Ghedira L. Study of genotoxic, antigenotoxic and antioxidant activities of the digallic acid isolated from Pistacialentiscus fruits. Toxicology in Vitro. 2010 Mar 1;24(2):509-515. 
31. Ammari M, Othman H, Hajri A, Sakly M, Abdelmelek H.Pistacialentiscus oil attenuates memory dysfunction and decreases levels of biomarkers of oxidative stress induced by lipopolysaccharide in rats. Brain research bulletin. 2018 Jun 1;140:140-147.

32. Samavati V, Adeli M. Isolation and characterization of hydrophobic compounds from carbohydrate matrix of Pistaciaatlantica. Carbohydrate polymers. 2014 Jan 30; 101:890-896.

33. Ahmed ZB, Yousfi M, Viaene J, Dejaegher B, Demeyer K, Mangelings D, Vander Heyden Y. Antioxidant activities of Pistaciaatlantica extracts modeled as a function of chromatographic fingerprints in order to identify antioxidant markers. Microchemical journal. 2016 Sep 1;128:208-217.

34. Ghasemynasabparizi M, Ahmadi A, Mazloomi SM. A review on pistachio: Its composition and benefits regarding the prevention or treatment of diseases. Journal of Occupational Health and Epidemiology. 2015;4(1):57-69.

35.Pareek V, Bhargava A, Gupta R, Jain N, Panwar J. Synthesis and applications of noble metal nanoparticles: a review. Advanced Science, Engineering and Medicine. 2017 Jul $1 ; 9(7): 527-544$.

36. Keat CL, Aziz A, Eid AM, Elmarzugi NA. Biosynthesis of nanoparticles and silver nanoparticles. Bioresources and Bioprocessing. 2015 Dec;2(1):47.

37. Veisi H, Faraji AR, Hemmati S, Gil A. Green synthesis of palladium nanoparticles using Pistaciaatlanticakurdica gum and their catalytic performance in Mizoroki-Heck and SuzukiMiyaura coupling reactions in aqueous solutions. Applied Organometallic Chemistry. 2015 Aug;29(8):517-23.

38. Shankar S, Teng X, Li G, Rhim JW. Preparation, characterization, and antimicrobial activity of gelatin/ZnO nanocomposite films. Food Hydrocolloids. 2015 Mar 1;45:264-2671.

39. Koblihová E, Mrazova I, Vernerova Z, Ryska M. Acute liver failure induced by thioacetamide: selection of optimal dosage in Wistar and Lewis rats. Physiological research. 2014 Aug 1;63(4).

40. Buege JA, Aust SD. Microsomal lipid peroxidation. InMethods in enzymology 1978 Jan 1 (Vol. 52, pp. 302-310). Academic Press.

41. Moron MS, Depierre JW, Mannervik B. Levels of glutathione, glutathione reductase and glutathione S-transferase activities in rat lung and liver. BiochimicaetBiophysicaActa (BBA)-General Subjects. 1979 Jan 4;582(1):67-78. 
42. Nishikimi M, Rao NA, Yagi K. The occurrence of superoxide anion in the reaction of reduced phenazinemethosulfate and molecular oxygen. Biochemical and biophysical research communications. 1972 Jan 31;46(2):849-854.

43. Moshage H, Kok B, Huizenga JR, Jansen PL. Nitrite and nitrate determinations in plasma: a critical evaluation. Clinical chemistry. 1995 Jun 1;41(6):892-896.

44. Bradford MM. A rapid and sensitive method for the quantitation of microgram quantities of protein utilizing the principle of protein-dye binding. Analytical biochemistry. 1976; $72(1-2), 248-254$.

45. MasoomiKarimi M, Jafari Sani M, ZareeMahmudabadi A, Khatibi SR. Effect of acute toxicity of cadmium in mice kidney cells. Iranian Journal of Toxicology. 2012 Oct 15;6(18):691-698.

46. Slaoui M, Fiette L. Histopathology procedures: from tissue sampling to histopathological evaluation. In Drug safety Evaluation 2011 (pp. 69-82). Humana Press.

47. Zweig MH, Campbell G. Receiver-operating characteristic (ROC) plots: a fundamental evaluation tool in clinical medicine. Clinical chemistry. 1993 Apr 1;39(4):561-577.

48. Jaeschke H, McGill MR, Ramachandran A. Oxidant stress, mitochondria, and cell death mechanisms in drug-induced liver injury: lessons learned from acetaminophen hepatotoxicity. Drug metabolism reviews. 2012 Feb 1;44(1):88-106.

49.Bruck R, Aeed H, Shirin H, Matas Z, Zaidel L, Avni Y, Halpern Z. The hydroxyl radical scavengersdimethylsulfoxide and dimethylthiourea protect rats against thioacetamideinduced fulminant hepatic failure. Journal of hepatology. 1999 Jul 1;31(1):27-38.

50. Ansil PN, Nitha A, Prabha SP, et al.. Protective effect of Amorphophalluscampanulatus (Roxb.) Blume. tuber against thioacetamide induced oxida-tive stress in rats. Asian Pacific Journal of Tropical Medicine. 2011; 4: 870-877.

51. Hajovsky H, Hu G, Koen Y, Sarma D, Cui W, Moore DS, Staudinger JL, Hanzlik RP. Metabolism and toxicity of thioacetamide and thioacetamide S-oxide in rat hepatocytes. Chemical research in toxicology. 2012 Aug 17;25(9):1955-1963.

52. Li S, Tan HY, Wang N, Cheung F, Hong M, Feng Y. The potential and action mechanism of polyphenols in the treatment of liver diseases. Oxidative medicine and cellular longevity. 2018; 2018.

53. Ricordi C, Garcia-Contreras M, Farnetti S. Diet and inflammation: possible effects on immunity, chronic diseases, and life span. Journal of the American College of Nutrition. 2015 Sep 15;34(sup1):10-13. 
54. Şahin B, Demir E, Aygün A, Gündüz H, Şen F. Investigation of the effect of pomegranate extract and monodisperse silver nanoparticle combination on MCF-7 cell line. Journal of biotechnology. 2017 Oct 20; 260:79-83.

55. Fontana L, Moreira E, Torres MI, Fernández MI, Rios A, De Medina FS, Gil A. Serum amino acid changes in rats with thioacetamide-induced liver cirrhosis. Toxicology. 1996 Jan 8;106(1-3):197-206.

56. Alshawsh MA, Abdulla MA, Ismail S, Amin ZA.Hepatoprotective effects of Orthosiphonstamineus extract on thioacetamide-induced liver cirrhosis in rats. EvidenceBased Complementary and Alternative Medicine. 2011;2011.

57. Binduja S, Visen PK, Dayal R, Agarwal DP, Patnaik GK. Protective action of ursolic acid against chemical induced hepato-toxicity in rats. Indian Journal of Pharmacology. 1996 Oct $1 ; 28(4): 232$.

58. Gullon B, Pintado ME, Pérez-Álvarez JA, Viuda-Martos M. Assessment of polyphenolic profile and antibacterial activity of pomegranate peel (Punicagranatum) flour obtained from co-product of juice extraction. Food Control. 2016 Jan 1; 59:94-98.

59. Amri Z, Zaouay F, Lazreg-Aref H, Soltana H, Mneri A, Mars M, Hammami M. Phytochemical content, fatty acids composition and antioxidant potential of different pomegranate parts: comparison between edible and non-edible varieties grown in Tunisia. International journal of biological macromolecules. 2017 Nov 1;104:274-280.

60. Husain H, Latief U, Ahmad R. Pomegranate action in curbing the incidence of liver injury triggered by Diethylnitrosamine by declining oxidative stress via Nrf2 and NFkB regulation. Scientific reports. 2018 Jun 5;8(1):8606.

61. Bachoual R, Talmoudi W, Boussetta T, Braut F, El-Benna J. An aqueous pomegranate peel extract inhibits neutrophil myeloperoxidase in vitro and attenuates lung inflammation in mice. Food and Chemical Toxicology. 2011 June 1;49(6):1224-1228.

62. Esmaillzadeh A, Tahbaz F, Gaieni I, Alavi-Majd H, Azadbakht L. Cholesterol-lowering effect of concentrated pomegranate juice consumption in type II diabetic patients with hyperlipidemia. International journal for vitamin and nutrition research. 2006 May 1; 76(3):147-151.

63. Al-Shaaibi SN, Waly MI, Al-Subhi L, Tageldin MH, Al-Balushi NM, Rahman MS. Ameliorative effects of pomegranate peel extract against dietary-induced nonalcoholic fatty liver in rats. Preventive nutrition and food science. 2016 Mar;21(1):14.

64. Kocyigit A, Koylu AA, Keles H. Effects of pistachio nuts consumption on plasma lipid profile and oxidative status in healthy volunteers. Nutrition, metabolism and cardiovascular diseases. 2006 Apr 1;16(3):202-209. 
65. Sheridan MJ, Cooper JN, Erario M, Cheifetz CE. Pistachio nut consumption and serum lipid levels. Journal of the American College of Nutrition. 2007 Apr 1;26(2):141-148.

66. Kay CD, Gebauer SK, West SG, Kris-Etherton PM. Pistachios increase serum antioxidants and lower serum oxidized-LDL in hypercholesterolemic adults. The Journal of nutrition. 2010 Mar 31;140(6):1093-1098.

67. Zhao X, Sun H, Hou A, Zhao Q, Wei T, Xin W. Antioxidant properties of two gallotannins isolated from the leaves of Pistaciaweinmannifolia. BiochimicaetBiophysicaActa (BBA)General Subjects. 2005 Aug 30;1725(1):103-110.

68. Gholamian-Dehkordi N, Luther T, Asadi-Samani M, Mahmoudian-Sani MR. An overview on natural antioxidants for oxidative stress reduction in cancers; a systematic review. ImmunopathologiaPersa. 2017 Feb 11;3(2).

69. Vítek L, Jirsa Jr M, Brodanová M, Kaláb M, Mareček Z, Danzig V, Novotný L, Kotal P. Gilbert syndrome and ischemic heart disease: a protective effect of elevated bilirubin levels. Atherosclerosis. 2002 Feb 1;160(2):449-456.

70. Hamoud AR, Weaver L, Stec DE, Hinds Jr TD. Bilirubin in the liver-gut signaling Axis. Trends in Endocrinology \& Metabolism. 2018 Mar 1;29(3):140-150.

71. Li F, Lang F, Wang Y, Zhai C, Zhang C, Zhang L, Hao E. Cyanidin ameliorates endotoxin-induced myocardial toxicity by modulating inflammation and oxidative stress through mitochondria and other factors. Food and chemical toxicology. 2018 Oct 1;120:104-111.

72. Iwakiri Y, Kim MY. Nitric oxide in liver diseases. Trends in Pharmacological sciences. 2015 Aug 1;36(8):524-536.

73. Liu X, Chen K, Zhu L, Liu H, Ma T, Xu Q, Xie T. Soyasaponin Ab protects against oxidative stress in HepG2 cells via Nrf2/HO-1/NQO1 signaling pathways. Journal of functional foods. 2018a Jun 1; 45:110-117.

74. Keshari AK, Srivastava R, Singh P, Yadav VB, Nath G. Antioxidant and antibacterial activity of silver nanoparticles synthesized by Cestrum nocturnum. Journal of Ayurveda and integrative medicine. 2018 Aug 16.

75. Ammar A, Turki M, Hammouda O, Chtourou H, Trabelsi K, Bouaziz M, Abdelkarim O, Hoekelmann A, Ayadi F, Souissi N, Bailey S. Effects of pomegranate juice supplementation on oxidative stress biomarkers following weightlifting exercise. Nutrients. 2017;9(8):819.

76. Mollazadeh H, Sadeghnia HR, Hoseini A, Farzadnia M, Boroushaki MT. Effects of pomegranate seed oil on oxidative stress markers, serum biochemical parameters and pathological findings in kidney and heart of streptozotocin-induced diabetic rats. Renal failure. 2016 Sep 13;38(8):1256-1266. 
77. Alturfan AA, Alturfan EE, Uslu E. Pistachio Consumption has Beneficial Effects in Diabetic Rat Model. FÜ SağBil Tıp Derg. 2009;23:131-135.

78. Hussain T, Tan B, Yin Y, Blachier F, Tossou MC, Rahu N. Oxidative stress and inflammation: what polyphenols can do for us?. Oxidative Medicine and Cellular Longevity. 2016;2016.

79. Mannaa FA, Abdel-Wahhab KG. Physiological potential of cytokines and liver damages. Hepatoma Res. 2016; 2:131-143.

80. Del Campo JA, Gallego P, Grande L. Role of inflammatory response in liver diseases: Therapeutic strategies. World journal of hepatology. 2018 Jan 27;10(1):1.

81. Wang X, Shen C, Yang J, Yang X, Qin S, Zeng H, Wu X, Tang S, Zeng W. AlphaFetoprotein as a Predictive Marker for Patients with Hepatitis B-Related Acute-on-Chronic Liver Failure. Canadian Journal of Gastroenterology and Hepatology. 2018; 2018.

82. Hessin AF, Hegazy RR, Hassan AA, Yassin NZ, Kenawy SA. Resveratrol prevents liver fibrosis via two possible pathways: Modulation of alpha fetoprotein transcriptional levels and normalization of protein kinase $\mathrm{C}$ responses. Indian journal of pharmacology. $2017 \mathrm{Jul}$; 49(4):282.

83. Patial S, Luo J, Porter KJ, Benovic JL, Parameswaran N. G-protein-coupled-receptor kinases mediate $\mathrm{TNF} \alpha$-induced NF- $\kappa B$ signalling via direct interaction with and phosphorylation of I $\kappa \mathrm{B} \alpha$. Biochemical Journal. 2010 Jan 1; 425(1):169-180.

84. Li F, Lang F, Wang Y, Zhai C, Zhang C, Zhang L, Hao E.Cyanidin ameliorates endotoxin-induced myocardial toxicity by modulating inflammation and oxidative stress through mitochondria and other factors. Food and chemical toxicology. 2018 Oct 1; 120:104-111.

85. Coursodon-Boyiddle CF, Snarrenberg CL, Adkins-Rieck CK, Bassaganya-Riera J, Hontecillas R, Lawrence P, Brenna JT, Jouni ZE, Dvorak B. Pomegranate seed oil reduces intestinal damage in a rat model of necrotizing enterocolitis. American Journal of Physiology-Gastrointestinal and Liver Physiology. 2012 Jul 19; 303(6):G744-751.

86. Grace MH, Esposito D, Timmers MA, Xiong J, Yousef G, Komarnytsky S, Lila MA. Chemical composition, antioxidant and anti-inflammatory properties of pistachio hull extracts. Food chemistry. 2016 Nov 1; 210:85-95.

87. Paterniti I, Impellizzeri D, Cordaro M, Siracusa R, Bisignano C, Gugliandolo E, Carughi A, Esposito E, Mandalari G, Cuzzocrea S. The anti-inflammatory and antioxidant potential of pistachios (Pistaciavera L.) in vitro and in vivo. Nutrients. 2017 Aug; 9(8):915.

88. Nishizawa K, Nishizawa M. Extracellular Heat Shock Proteins as a Natural Protector of Cells and Organisms: A Review of Recent Studies. Ann Biomed Res. 2018; 1(2):109. 
89. Kuramochi M, Izawa T, Pervin M, Bondoc A, Kuwamura M, LaMarre J, Yamate J. Attenuation of thioacetamide-induced hepatocellular injury by short-term repeated injections associated with down-regulation of metabolic enzymes and relationship with MHC class II-presenting cells. Experimental and toxicologic pathology. 2017 Oct 2; 69(8):589-597.

90. Mahjoub F, Rezayat KA, Yousefi M, Mohebbi M, Salari R.PistaciaatlanticaDesf. A review of its traditional uses, phytochemicals and pharmacology. Journal of medicine and life. $2018 \mathrm{Jul} ; 11(3): 180$.

91. Hu R, He Y, Arowolo MA, Wu S, He J. Polyphenols as Potential Attenuators of Heat Stress in Poultry Production. Antioxidants. 2019 Mar; 8(3):67.

92. Ibrahim ZS, Nassan MA, Soliman MM. Ameliorative effects of pomegranate on carbon tetrachloride hepatotoxicity in rats: A molecular and histopathological study. Molecular medicine reports. 2016 Apr 1; 13(4):3653-3660.

93. Bishayee A, Thoppil RJ, Darvesh AS, Ohanyan V, Meszaros JG, Bhatia D. Pomegranate phytoconstituents blunt the inflammatory cascade in a chemically induced rodent model of hepatocellular carcinogenesis. The Journal of nutritional biochemistry. 2013 Jan 1; 24(1):178-187.

94. Afifi NA, Ramadan A, El-Eraky W, Salama AAA, El-Fadaly AA and Hassan A. Quercetin protects against thioacetamide induced hepato-toxicity in rats through decreased oxidative stress biomarkers, the inflam-matory cytokines; (TNF-), (NF-B) and DNA fragmentation. Der PharmaChem. 2016; 8(9): 48-55.

95. Chen LH, Hsu CY, Weng CF. Involvement of P53 and Bax/Bad triggering apoptosis in thioacetamide-induced hepatic epithelial cells. World Journal of Gastroenterology: WJG. 2006 Aug 28; 12(32):5175.

96. EL-LEITHY. Eman S.; HASSAN A. Sohair.; ABDEL-RASHID, Rania S. Tamoxifen citrate/coenzyme Q10 as smart nanocarriersbitherapy for breast cancer: cytotoxicity, genotoxicity, and antioxidant activity. Journal of Drug Delivery Science and Technology, 2019 51; 36-44...

97. Majidinia M, Bishayee A, Yousefi B. Polyphenols: Major regulators of key components of DNA damage response in cancer. DNA repair. 2019 Aug; 8:102679

98. OTHMAN S, El-Hashash M, Hussein S, El-Mesallamy A, Rizk S, \&Elabbar F A. Phenolic Content as Antioxidant and Antimicrobial Activities of Pistacia atlantica Desf.(Anacardiaceae) Extract from Libya. Egyptian Journal of Chemistry, 2019, 62.1: 21-28). 
bioRxiv preprint doi: https://doi.org/10.1101/2020.05.06.071001; this version posted May 8, 2020. The copyright holder for this preprint (which was not certified by peer review) is the author/funder, who has granted bioRxiv a license to display the preprint in perpetuity. It is made available under aCC-BY-NC 4.0 International license. 